\title{
ANALISIS DAMPAK KEBIJAKAN MAKROEKONOMI TERHADAP PERKEMBANGAN INDUSTRI TEKSTIL DAN PRODUK TEKSTIL INDONESIA
}

\author{
Iwan Hermawan, SP. MSi ${ }^{1}$
}

\begin{abstract}
Textile and textile's product play an important role in the Indonesian economy. During the last five years, however, share of these industries and commodities to gross domestic product tend to decrease. The objectives of this study are to analyze factors affecting Indonesian textile and textile's product, and the prospect of Indonesian textile and textile's product in the future. Results of the study show that domestic textile production was affected by world cotton price and wage rate, while the domestic garment production was affected by wage rate in the garment sector. Indonesia's textile export to world market was influenced by domestic textile price, and Indonesia's export garment was influenced by exchange rate (Rp/US\$). Indonesian textile demand was affected by wage rate and domestic garment demand was affected by income per capita of Indonesia. In general, the prospect of Indonesian textile and textile's product seems not too good. In fact, Indonesian textile and textile's product had depended on high import cotton, investment, and exchange rate. So why, economy policies are still needed to accelerate Indonesian textile and textile's product development.
\end{abstract}

JEL Classification Number: C53, E60, F43, and F4.

Keyword: export, open economy, forecasting, simulation, textile and textile's product.

1 Calon Peneliti Bidang Ekonomi dan Kebijakan Publik, P3DI, Setjen DPR RI. Alamat email: iwan.h@hotmail.com 


\section{PENDAHULUAN}

Industri tekstil dan produk tekstil (TPT) menawarkan kesempatan yang penting bagi suatu negara untuk memulai industrialisasi ekonominya. Industri ini memainkan peranan penting dalam meningkatkan orientasi ekspor di negara-negara Asia, seperti Hong Kong, Singapura, Taiwan, Korea Selatan, Malaysia, Cina, Indonesia, Thailand, dan Vietnam. ${ }^{2}$ Selain itu jumlah penduduk negara Association of Southeast Asian Nations (ASEAN) yang mencapai sekitar 597 juta orang ${ }^{3}$ dan penerapan ASEAN single window (ASW) dengan bea masuk 0 persen (kecuali negara Laos, Kamboja, dan Myanmar menerapkan free duty pada tahun 2012) menjadi peluang besar bagi pasar TPT (Sunarno, 2008) ${ }^{4}$.

Sektor TPT menjadi sektor kunci di negara Pakistan, Vietnam, Thailand, Sri Lanka, dan Indonesia. Pada tahun 2010 pertumbuhan ekspor TPT Vietnam mencapai sebesar US\$11,2 miliar $^{5}$. Di Indonesia, kinerja TPT juga memberikan kontribusi bagi pertumbuhan ekonomi di Indonesia. Industri TPT mempunyai kontribusi 2,18 persen terhadap Produk Domestik Bruto (PDB) dan 8,01 persen terhadap industri pengolahan pada tahun 2010 (BPS, 2008). Bahkan komoditas ekspor non migas yang memberikan kontribusi terbesar selama lebih dari 20 tahun terakhir adalah TPT. Peningkatan tersebut tidak terlepas dari kebijakan pemerintah pada awal pengembangan industri ini.

Industri TPT 6 juga penyumbang terbesar dalam perolehan devisa Indonesia. Pada tahun 2009, industri TPT berkontribusi sebesar 12,72 persen dalam perolehan devisa terhadap ekspor hasil industri tidak termasuk minyak dan gas (migas) dan sebesar 9,58 persen terhadap total ekspor non migas, meskipun 85 persen bahan baku berupa kapas masih diimpor. Nilai tersebut meningkat tajam dari hanya sebesar US\$ 559 juta pada tahun 1985 (BPS, 2010). Selain mempunyai kontribusi yang besar di dalam PDB dan devisa, industri ini juga menyerap banyak tenaga kerja, baik yang bekerja secara langsung ataupun tidak langsung.

Arti penting TPT dapat dilihat dari perannya sebagai salah satu kebutuhan dasar manusia selain pangan dan papan. Oleh karena itu, konsumsi sandang akan cenderung meningkat seiring dengan laju pertumbuhan penduduk (Grafik 1). Potensi pasar Indonesia untuk komoditas TPT relatif besar sebab kebutuhan kain masyarakat perkotaan tidak hanya berupa pakaian, tapi

2 UNCTAD. TNCs and the Removal of Textiles and Clothing Quotas. Geneva: United Nations Conference on Trade and Development, 2005, hal 3.

3 PRB. World Population Data Sheet 2009. Washington DC: Population Reference Bureau and USAID, 2009, hal. 8.

4 Susanna Sunarno. ASEAN, Basis Produksi TPT Dunia. IndonesianTextile.com. Serial Online. 2008. http://indonesia textile.com/ index.php?option=com_content\&task=view\&id=73\&ltemid=50. Diakses tanggal 17 Maret 2010.

5 VBN. Vietnam Textile and Garment Export Cross \$11.2 Biliion in 2010. Vitenam Business News. SerialOnline, 2011. http:// vietnambusiness.asia/vietnam-textile-and-garment-exports-cross-11-2b-in-2010/. Diakses tanggal 10 Januari 2011

6 Ekspor hasil industri pakaian jadi dan tekstil lainnya. 


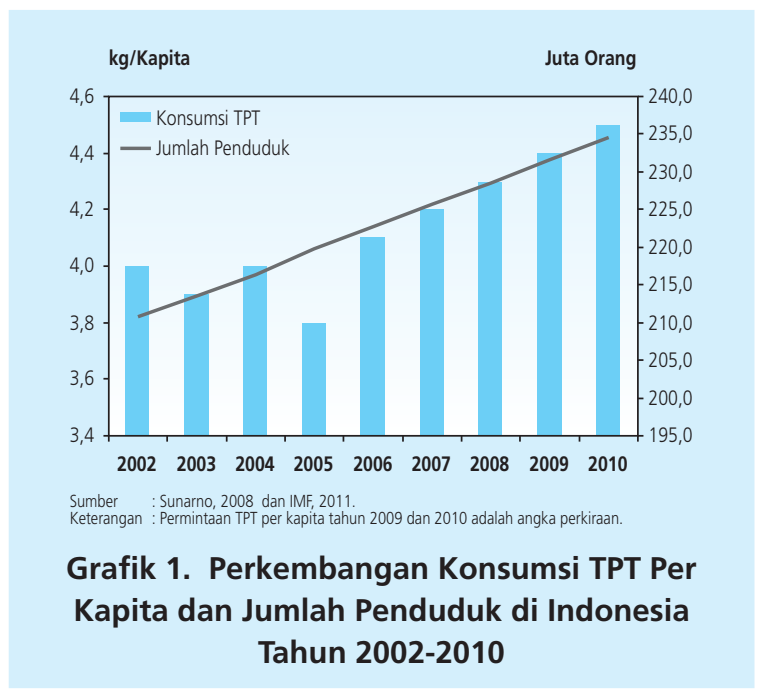

juga kebutuhan non pakaian. Pada tahun 2005 konsumsi TPT Indonesia menurun secara signifikan dibandingkan tahun 2004. Hal ini karena pada tanggal 1 Januari 2005, sistem kuota dicabut dan disesuaikan dengan ketentuan General Agreement on Tariffs and Trade (GATT). Kesepakatan tersebut dimulai dari Putaran Uruguay tanggal 15 April 1994 di Marakesh yang menghasilkan Agreement on Textile and Clothing (ATC) terhadap menetapkan sistem kuota impor.

Di sisi lain perubahan sistem kuota tersebut akan berdampak positif bagi perkembangan industri TPT melalui perdagangan yang lebih adil dan menandai era baru perdagangan TPT dunia. Sistem kuota TPT yang bersifat diskriminasi dihapuskan dan market share TPT semakin besar melalui persaingan internasional serta peluang pengembangan industri TPT akan semakin besar. Indonesia adalah salah satu di antara negara-negara produsen TPT terbesar di dunia. Pada tahun 2000 ekspor TPT Indonesia mencapai sebesar US\$ 8,2 miliar (Rp. 74,9 triliun) dan menduduki ranking 10 di antara negara produsen TPT dunia. Tahun 2003, ekspor TPT Indonesia hanya mencapai US\$7,03 miliar, hal ini membuat posisi ranking menurun menjadi 17. Namun pada tahun 2004, sektor ini mampu menaikan perolehan devisa sebesar US\$ 7,6 miliar. Menurut Thuborn, $2010^{8}$ pada tahun 2007 secara keseluruhan nilai ekspor TPT Indonesia sebesar US\$ 9,73 miliar, dimana menduduki ranking 12 untuk ekspor tekstil dan ranking 8 untuk ekspor garmen.

7 Susanna Sunarno. Amankan Pasar Dalam Negeri. www.indonesiatextile.com. Serial Online, 2008. http://indonesiatextile. com/ index.php?option=com_content\&task=view\&id=76\&ltemid=50, Diakses Tanggal 17 Maret 2010.

8 John Thoburn. The Impact of World Recession on the Textile and Garment Industries of Asia. Working Paper No. 17. Vienna: United Nations Industrial Development Organization, 2010, hal. 31. 
Gambaran di atas mengindikasikan bahwa industri TPT Indonesia mempunyai potensi dan peluang perkembangan yang cukup baik. Hal ini didukung oleh kemampuan industri TPT dalam memberikan kontribusi terhadap PDB, perolehan devisa. dan sekaligus penyerapan tenaga kerja. Selain itu industri TPT mempunyai peluang yang besar, dimana permintaan TPT akan meningkat seiring dengan pertumbuhan penduduk. Namun demikian, potensi dan peluang perkembangan industri TPT tersebut bukan tanpa kendala. Kendala-kendala yang dihadapi industri TPT dikhawatirkan dapat mengganggu atau menurunkan kontribusinya terhadap pembangunan ekonomi Indonesia.

Globalisasi yang ditandai dengan berakhirnya sistem kuota tahun 2005 telah mendorong perdagangan TPT dunia semakin terbuka dan mengubah peta pasar dari sisi supply manajemen importir. Perubahan perdagangan TPT dunia menimbulkan peluang dan ancaman bagi industri TPT Indonesia. Peluang yang muncul adalah pangsa pasar negara-negara yang selama ini terlindungi oleh sistem kuota akan menjadi terbuka. Sedangkan ancaman industri TPT Indonesia adalah kompetisi yang ketat antar negara-negara produsen TPT di dunia, seperti Cina, India, Amerika Serikat, dan Uni Eropa. Isu-isu non tarrif barrier, seperti transshipment dan dumping ikut mempengaruhi arus penetrasi perdagangan TPT dari negara berkembang ke negara maju.

Sementara persaingan di pasar dunia semakin meningkat, kondisi industri TPT di dalam negeri justru relatif memprihatinkan. Salah satu keadaan yang memperburuk prospek perkembangan industri TPT di Indonesia adalah iklim investasi yang sangat tidak kondusif. Padahal industri TPT sangat membutuhkan investasi yang besar untuk merevitalisasi mesinmesin maupun teknologi yang sudah tua. Iklim investasi yang tidak kondusif disebabkan antara lain, belum adanya kepastian hukum, meluasnya korupsi, birokrasi yang berbelit-belit masalah tenaga kerja, dan perpajakan.

Pada tahun 1997 krisis moneter yang melanda negara-negara Asia Timur, termasuk Indonesia, mengakibatkan nilai tukar Rupiah terdepresiasi. Hal ini seharusnya membuat produk TPT Indonesia lebih kompetitif bagi konsumen luar negeri, karena harga TPT Indonesia menjadi lebih murah. Namun kenyataannya nilai ekspor TPT menurun hingga US\$1,3 miliar pada tahun 1997 (CIC, 2001).

Dengan berbagai permasalahan tersebut di atas, apakah industri TPT masih mampu bertahan atau berkembang? Oleh sebab itu adalah penting untuk menganalisis faktor-faktor yang mempengaruhinya serta prospek industri TPT Indonesia di masa depan. Tujuan penelitian ini adalah untuk: (1) menganalisis faktor-faktor yang mempengaruhinya perkembangan industri TPT Indonesia, dan (2) menganalisis prospek perkembangan industri TPT Indonesia di masa mendatang. Hasil penelitian diharapkan dapat memberikan masukan bagi penyusunan kebijakan yang mampu mendukung perkembangan industri TPT Indonesia. 
Bagian kedua dari paper ini akan mengulas teori dan tinjauan empiris industri tekstil, bagian ketiga mengulas metodologi penelitian yang digunakan, sementara hasil dan analisis akan diuraikan pada bagian keempat. Kesimpulan menjadi bagian penutup.

\section{TEORI}

\subsection{Teori Keseimbangan Umum Perdagangan}

Pada dasarnya beberapa faktor yang mendorong timbulnya perdagangan internasional suatu negara dengan negara lainnya bersumber dari keinginan untuk memperluas pemasaran komoditas ekspor, memperbesar devisa bagi kegiatan pembangunan, perbedaan penawaran dan permintaan antar negara, serta akibat perbedaan biaya relatif dalam menghasilkan komoditas tertentu (Gonarsyah, 1987).

Pada Grafik 2 dijelaskan bagaimana perdagangan dapat terjadi antara dua negara (Indonesia dan Cina) dan antara dua komoditas (garmen dan beras). Perdagangan terjadi karena adanya perbedaan slope yang menunjukkan rasio harga relatif antara beras dan garmen. Asumsi yang digunakan meliputi, yaitu hanya ada dua negara yang melakukan perdagangan, constant opportunity costs dan masing-masing negara berusaha mencapai tingkat kesejahteraan yang paling tinggi (titik tangen antara kurva indiferen dan garis barter).

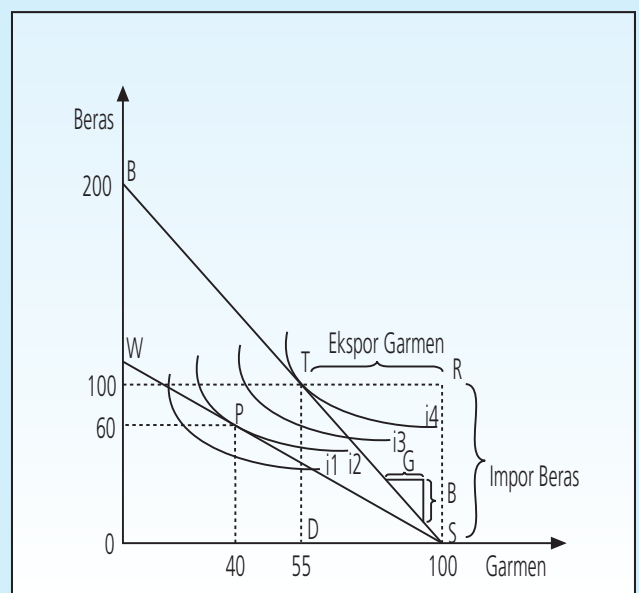

a. Indonesia

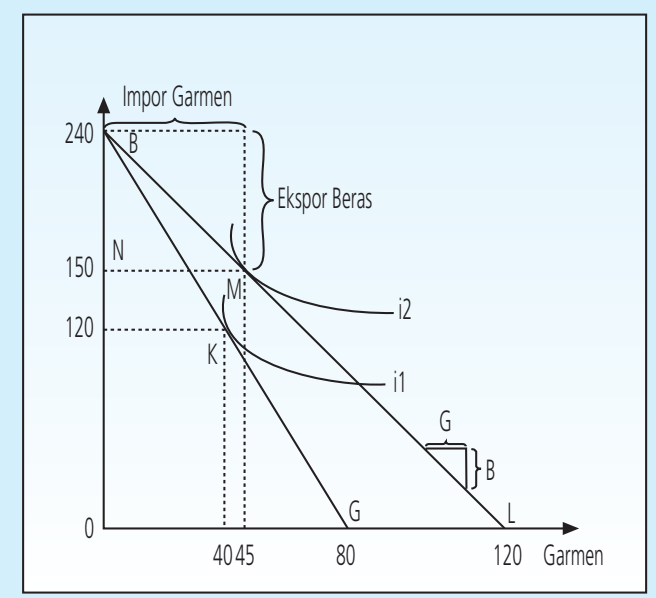

b. Cina

Grafik 2.

Keseimbangan Umum Perdagangan 
Sebelum perdagangan terjadi (autarki), rasio pertukaran domestik adalah berbeda pada dua negara tersebut. Hal ini juga menunjukkan adanya perbedaan comparative advantage, dimana garmen relatif lebih murah di Indonesia daripada di Cina. Ketika perdagangan dimulai antara dua negara, rasio pertukaran internasional (term of trade) mendasari antara dua rasio domestik, misalkan 1 garmen:1 beras dan 1 garmen:3 beras. Rasio pertukaran internasional tersebut akan berimbang tergantung pada willingness setiap negara untuk menawarkan komoditas ekspornya dan membeli impor pada harga relatif.

Pada posisi keseimbangan akhir, Indonesia akan memproduksi pada titik $\mathrm{S}$ dan mengkonsumsi pada titik T. Dimana Indonesia memproduksi garmen sebesar OS (100 juta ton), konsumsi dalam negeri sebesar OD (55 juta ton), dan ekspor sebesar SD (45 juta ton) yang akan ditukar dengan impor beras sebesar DT (90 juta ton). Segitiga TRS adalah segitga perdagangan. TR merepresentasikan ekspor dari garmen, RS merepresentasikan impor dari beras, dan slope TS merepresentasikan harga relatif garmen. Manfaat perdagangan juga akan diperoleh oleh Cina dari mengimpor garmen dan mengekspor beras, dimana gain perdagangan secara total dapat dilihat pada Tabel 1. Jadi tanpa perdagangan, konsumsi beras Cina hanya sebesar 120 juta ton dan garmen sebesar 40 juta ton. Setelah melakukan perdagangan dengan Indonesia, ekspor beras Cina meningkatkan sebesar NB (90 juta ton) dan impor garmen Cina meningkat sebesar NM (45 juta ton).

\begin{tabular}{|c|c|c|c|c|c|c|c|c|}
\hline \multirow{2}{*}{$\begin{array}{l}\text { Negara/ } \\
\text { Wilayah }\end{array}$} & \multicolumn{4}{|c|}{ Beras } & \multicolumn{4}{|c|}{ Garmen } \\
\hline & $\begin{array}{l}\text { Produksi } \\
\text { (1) }\end{array}$ & $\begin{array}{l}\text { Ekspor } \\
\text { (2) }\end{array}$ & $\begin{array}{l}\text { Impor } \\
\text { (3) }\end{array}$ & $\begin{array}{c}\text { Konsumsi } \\
(4)=(1)-(2)+(3)\end{array}$ & $\begin{array}{l}\text { Produksi } \\
\text { (1) }\end{array}$ & $\begin{array}{c}\text { Ekspor } \\
\text { (2) }\end{array}$ & $\begin{array}{l}\text { Impor } \\
\text { (3) }\end{array}$ & $\begin{array}{c}\text { Konsumsi } \\
(4)=(1)-(2)+(3)\end{array}$ \\
\hline \multicolumn{9}{|c|}{ Sebelum Perdagangan } \\
\hline $\begin{array}{l}\text { Cina } \\
\text { Indonesia } \\
\text { Dunia } \\
\end{array}$ & $\begin{array}{c}120 \\
60 \\
180 \\
\end{array}$ & $\begin{array}{l}- \\
- \\
-\end{array}$ & $\begin{array}{l}- \\
- \\
-\end{array}$ & $\begin{array}{c}120 \\
60 \\
180 \\
\end{array}$ & $\begin{array}{l}40 \\
40 \\
80\end{array}$ & $\begin{array}{l}- \\
- \\
-\end{array}$ & $\begin{array}{l}- \\
- \\
-\end{array}$ & $\begin{array}{l}40 \\
40 \\
80\end{array}$ \\
\hline \multicolumn{9}{|c|}{ Setelah Perdagangan } \\
\hline $\begin{array}{l}\text { Cina } \\
\text { Indonesia } \\
\text { Dunia }\end{array}$ & $\begin{array}{c}240 \\
0 \\
240\end{array}$ & $\begin{array}{c}90 \\
0\end{array}$ & $\begin{array}{c}0 \\
90\end{array}$ & $\begin{array}{c}150 \\
90 \\
240\end{array}$ & $\begin{array}{c}0 \\
100 \\
100\end{array}$ & $\begin{array}{c}0 \\
45\end{array}$ & $\begin{array}{c}45 \\
0\end{array}$ & $\begin{array}{c}45 \\
55 \\
100\end{array}$ \\
\hline \multicolumn{9}{|c|}{ Gain dari Perdagangan } \\
\hline $\begin{array}{l}\text { Cina } \\
\text { Indonesia } \\
\text { Dunia }\end{array}$ & & & & $\begin{array}{l}+30 \\
+30 \\
+60\end{array}$ & & & & $\begin{array}{r}+5 \\
+15 \\
+20\end{array}$ \\
\hline
\end{tabular}




\subsection{Konstruksi Model Ekonomi Tekstil dan Produk Tekstil Indonesia}

Berdasarkan teori perusahaan, permintaan input diturunkan dari fungsi produksi setiap perusahaan dengan asumsi produsen memaksimumkan keuntungan dengan kendala teknologi dan pasar (harga output dan input) (Varian, 1978 dalam Sinaga, 1989). Asumsi lainnya bahwa setiap perusahaan menghadapi pasar persaingan sempurna, baik pada pasar input maupun output, sehingga setiap perusahaan adalah price taker.

Penurunan permintaan input dan penawaran output tersebut membutuhkan syarat First Order Necessary Condition (FONC) dan Second Order Sufficient Condition (SOSC) dalam memaksimisasi keuntungan (Henderson dan Quandt, 1980). Diasumsikan bahwa fungsi produksi dapat diturunkan (twice differentiable), permintaan perusahaan terhadap input tertentu mensyaratkan kondisi produktivitas input (produk marginal) senilai dengan harganya. Komoditas tekstil sebagai derived demand dari komoditas garmen. Oleh sebab itu peubah-peubah yang terkandung di dalam persamaan permintaan tekstil domestik tampak berbeda dengan permintaan final goods seperti pada umumnya.

Dalam penelitian ini, juga diasumsikan bahwa hanya terdapat satu jenis tekstil dan garmen yang diperdagangkan. Oleh sebab itu tekstil dan garmen dianggap sebagai komoditas yang kemudian dikonversi dalam satuan berat yang sama (ton). Faktor konversi tersebut menggunakan perhitungan umum yang diaplikasikan oleh API. Sedangkan peubah harga komposit tekstil dan garmen di dalam negeri berdasarkan data yang diterbitkan oleh API dan peubah harga komposit tekstil dan garmen di luar negeri menggunakan proksi dari harga ekspor tekstil dan garmen dunia.

Selain itu, Indonesia adalah termasuk negara kecil yang terbuka (small open economy). Kategori negara kecil atau besar didasarkan pada perilaku ekonominya, dimana Indonesia tidak dapat mempengaruhi harga dunia atau peubah harga dunia sebagai peubah eksogenus (Krantz, 2006). Menurut Houck, 1986 bahwa negara impotir kecil menghadapi excess supply yang datar dan tidak mampu mempengaruhi harga dunia. Oleh sebab itu asumsi yang digunakan adalah negara kecil berperilaku sebagai

price taker, baik di pasar input maupun pasar output. Selain itu biaya transportasi adalah nol serta tidak ada hambatan perdagangan. Kondisi ini dikonstruksikan di dalam model dengan memposisikan peubah harga tekstil dan garmen dunia sebagai peubah eksogen pada persamaan produksi, ekspor, dan impor tekstil dan garmen domestik.

Hubungan ekonomi antara peubah dalam model diformulasikan berdasarkan teori ekonomi mikro, teori ekonomi makro, teori perdagangan internasional, dan hasil-hasil penelitian yang terkait. Tanda parameter dugaan menjadi bentuk lain dari hipotesis yang ditindaklanjuti 


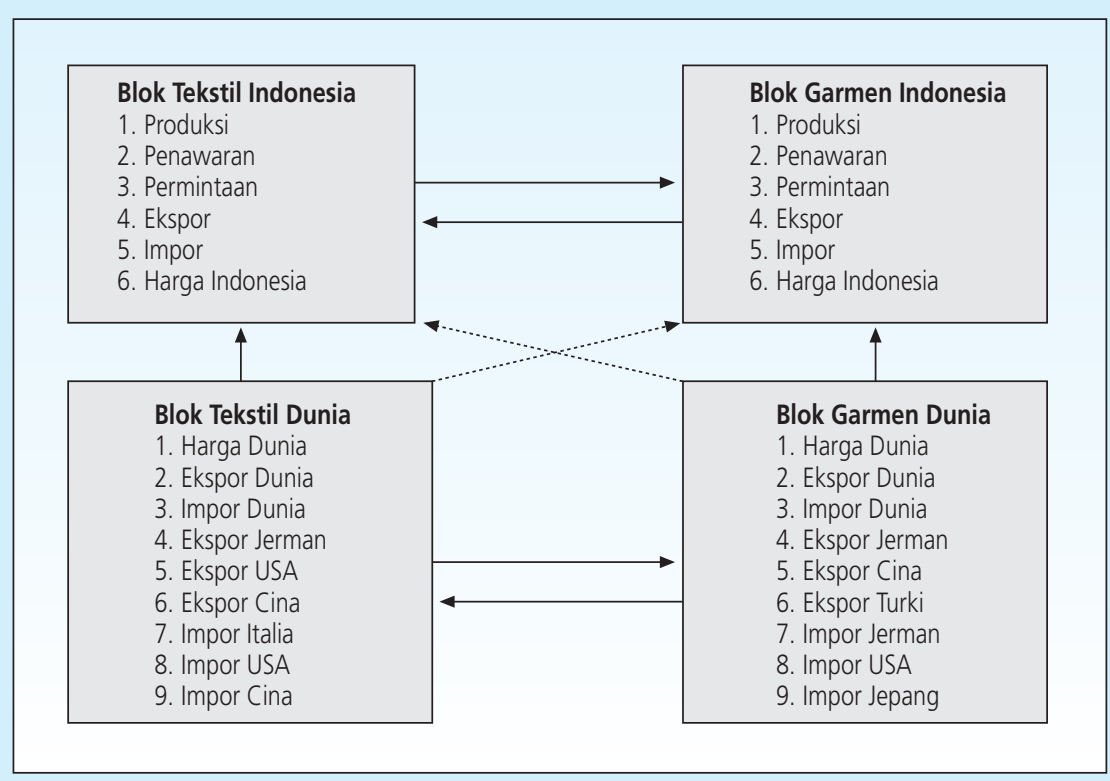

Gambar 1.

Keterkaitan Antar Blok dalam Model Ekonomi Tekstil dan Produk Tekstil Indonesia

sebagai landasan untuk menentukan metode analisis dan olah data yang sesuai. Keterkaitan antara industri TPT Indonesia dan dunia merupakan alasan model ini dikonstruksi dengan model dinamis dalam bentuk persamaan simultan (simultaneous equation). Sifat dinamis dari aspek penawaran, permintaan, harga di domestik, maupun harga dunia juga diakomodasikan dengan cara memasukkan peubah-peubah tahun sebelumnya ke dalam model. Pada Gambar 3 disajikan secara sederhana hubungan antara peubah endogen dan eksogen dalam blok pasar tekstil dan garmen di Indonesia dan dunia. Persamaan-persamaan tersebut dibagi dalam empat blok, yaitu (1) blok pasar tekstil Indonesia, (2) blok pasar garmen Indonesia, (3) blok pasar tekstil dunia, dan (4) blok pasar garmen dunia.

Sedangkan berdasarkan keterkaitan antar peubah dalam blok, maka disusun persamaanpersamaan yang terdiri dari peubah-peubah endogen dan eksogen. Penentuan peubah-peubah tersebut didasarkan pada kerangka teoritis, studi empiris, dan juga kondisi di lapangan. Peubahpeubah yang dipilih merupakan peubah yang dianggap berpengaruh dan terutama disesuaikan dengan ketersediaan data. Industri TPT terdiri dari sub sektor serat, benang, kain, pakaian jadi, dan tekstil lainnya. Tidak semua sub sektor tersebut akan dijelaskan secara eksplisit dalam model ekonomi. Sub sektor serat, benang, dan kain akan dimasukkan ke dalam kelompok 
tekstil, sedangkan pakaian jadi dan tekstil lainnya dimasukkan kelompok garmen. Alasan pengelompokan ini dilakukan karena sangat berkaitan dengan ketersediaan data. Model operasional yang dikembangkan dalam penelitian ini diupayakan dapat menangkap semua fenomena ekonomi dalam industri TPT, baik di pasar Indonesia maupun dunia. Model operasional terdiri 24 persamaan perilaku dan 6 persamaan identitas. Namun demikian hanya 12 persamaan perilaku dan 6 persamaan identitas yang dijelaskan lebih lanjut karena keterkaitannya langsung dengan industri TPT di dalam negeri. Perilaku ekspor tekstil dan garmen Jerman, Amerika Serikat, dan China Italia, Turki, dan Jepang tidak dijelaskan. Persamaan-persamaan tersebut disajikan sebagai berikut:

\section{Produksi tekstil domestik}

$$
\begin{aligned}
\text { PTD }_{\mathrm{t}}=\mathrm{a}_{0}+\mathrm{a}_{1} \operatorname{HTDR}_{\mathrm{t}-1}+\mathrm{a}_{2} \operatorname{HCWR}_{\mathrm{t}-1}+\mathrm{a}_{3}\left(\operatorname{IRR}_{\mathrm{t}}-\mathrm{IRR}_{\mathrm{t}-1}\right)+ \\
\mathrm{a}_{4} \text { UTKTR }_{\mathrm{t}-1}+\mathrm{a}_{5} \text { BBMR }_{\mathrm{t}-1}+\mathrm{a}_{6} \mathrm{~T}+\mathrm{a}_{7} \text { PTD }_{\mathrm{t}-1}+\mathrm{U}_{1}
\end{aligned}
$$

Tanda parameter dugaan yang diharapkan dalam persamaan adalah:

$\mathrm{a}_{1}, \mathrm{a}_{6}>0 ; \mathrm{a}_{2}, \mathrm{a}_{3}, \mathrm{a}_{4}, \mathrm{a}_{5}<0$ dan $0<\mathrm{a}_{7}<1$.

\section{Ekspor tekstil Indonesia}

$\mathrm{XTI}_{\mathrm{t}}=\mathrm{b}_{0}+\mathrm{b}_{1} \mathrm{HTWR}_{\mathrm{t}}+\mathrm{b}_{2}\left(\mathrm{HTDR}_{\mathrm{t}}-\mathrm{HTDR}_{\mathrm{t}-1}\right)+\mathrm{b}_{3} \mathrm{PTD}_{\mathrm{t}-1}+$

$$
\mathrm{b}_{4} \mathrm{ERIR}_{\mathrm{t}-1}+\mathrm{b}_{5} \mathrm{DKG}+\mathrm{b}_{6} \mathrm{~T}+\mathrm{b}_{7} \mathrm{XTI}_{\mathrm{t}-1}+\mathrm{U}_{2}
$$

Tanda parameter dugaan yang diharapkan dalam persamaan adalah:

$\mathrm{b}_{1}, \mathrm{~b}_{3}, \mathrm{~b}_{4}>0 ; \mathrm{b}_{2}<0$ dan $0<\mathrm{b}_{5}<1$.

\section{Penawaran tekstil domestik}

$$
\mathrm{STD}_{\mathrm{t}}=\mathrm{PTD}_{\mathrm{t}}+\mathrm{MTI}_{\mathrm{t}}-\mathrm{XTI}_{\mathrm{t}}
$$

\section{Permintaan tekstil domestik}

$$
\begin{aligned}
\text { DTD }_{\mathrm{t}}=\mathrm{c}_{0}+\mathrm{c}_{1}\left(\mathrm{HTWR}_{\mathrm{t}-1} / \mathrm{HTDR}_{\mathrm{t}}\right)+\mathrm{c}_{2} \mathrm{HGDR}_{\mathrm{t}-1}+\mathrm{c}_{3} \mathrm{UTKTR}_{\mathrm{t}-1}+ \\
\mathrm{c}_{4} \mathrm{BBM}_{\mathrm{t}-1}+\mathrm{c} 5\left(\operatorname{IRR}_{\mathrm{t}}-\mathrm{IRR}_{\mathrm{t}-1}\right)+\mathrm{c}_{6} \mathrm{~T}+\mathrm{c}_{7} \mathrm{DTD}_{\mathrm{t}-1}+\mathrm{U}_{3} \ldots
\end{aligned}
$$

Tanda parameter dugaan yang diharapkan dalam persamaan adalah: $\mathrm{c}_{1}, \mathrm{c}_{2}, \mathrm{c}_{3}, \mathrm{c}_{4}, \mathrm{c}_{5}<0 ; \mathrm{c}_{6}>0$ dan $0<\mathrm{c}_{7}<1$.

\section{Impor tekstil Indonesia}

$$
\begin{aligned}
& \text { MTI }_{t}=\mathrm{d}_{0}+\mathrm{d}_{1} \text { HMTIR }_{\mathrm{t}-1}+\mathrm{d}_{2}\left(\mathrm{HTWR}_{\mathrm{t}} / \mathrm{HCWR}_{\mathrm{t}}\right)+\mathrm{d}_{3} \text { TFT }_{\mathrm{t}-1}+\mathrm{d}_{4} \mathrm{ERIR}_{\mathrm{t}-1}+ \\
& \mathrm{d}_{5}\left(\text { GDPIR }_{\mathrm{t}} \text { GDPIR }_{\mathrm{t}-1}\right)+\mathrm{d}_{6} \text { POPI }_{\mathrm{t}-1}+\mathrm{d}_{7} \mathrm{~T}+\mathrm{d}_{8} \mathrm{MTI}_{\mathrm{t}-1}+\mathrm{U}_{4}
\end{aligned}
$$


Tanda parameter dugaan yang diharapkan dalam persamaan adalah:

$\mathrm{d}_{1}, \mathrm{~d}_{2}, \mathrm{~d}_{3}, \mathrm{~d}_{4}, \mathrm{~d}_{7}<0 ; \mathrm{d}_{5}, \mathrm{~d}_{6}>0$, dan $0<\mathrm{d}_{8}<1$.

\section{Harga tekstil domestik}

$$
\begin{aligned}
\operatorname{HTDR}_{\mathrm{t}}=\mathrm{e}_{0}+\mathrm{e}_{1} \operatorname{STD}_{\mathrm{t}-1}+\mathrm{e}_{2}\left(\mathrm{HGDR}_{\mathrm{t}}-\mathrm{HGDR}_{\mathrm{t}-1}\right)+ \\
\mathrm{e}_{3}\left(\mathrm{HTWR}_{\mathrm{t}-1} / \mathrm{HCWR}_{\mathrm{t}-1}\right)+\mathrm{e}_{4} \mathrm{HTDR}_{\mathrm{t}-1}+\mathrm{U}_{5}
\end{aligned}
$$

Tanda parameter dugaan yang diharapkan dalam persamaan adalah:

$\mathrm{e}_{1}<0 ; \mathrm{e}_{2}, \mathrm{e}_{3}>0$ dan $0<\mathrm{e}_{4}<1$.

\section{Harga tekstil dunia}

$\mathrm{HTWR}_{\mathrm{t}}=\mathrm{f}_{0}+\mathrm{f}_{1} \mathrm{XTW}_{\mathrm{t}}+\mathrm{f}_{2} \mathrm{MTW}_{\mathrm{t}-1}+\mathrm{f}_{3} \mathrm{HTWR}_{\mathrm{t}-1}+\mathrm{U}_{6}$

Tanda parameter dugaan yang diharapkan dalam persamaan adalah:

$\mathrm{f}_{1}<0 ; \mathrm{f}_{2}>0$ dan $0<\mathrm{f}_{3}<1$.

\section{Ekspor tekstil dunia}

$$
\mathrm{XTW}_{t}=\mathrm{XTI}_{\mathrm{t}}+\mathrm{XTG}_{\mathrm{t}}+\mathrm{XTA}_{\mathrm{t}}+\mathrm{XTC}_{\mathrm{t}}+\mathrm{XTR}_{\mathrm{t}}
$$

9. Impor tekstil dunia

$$
\mathrm{MTW}_{\mathrm{t}}=\mathrm{MTI}_{\mathrm{t}}+\mathrm{MTL}_{\mathrm{t}}+\mathrm{MTA}_{\mathrm{t}}+\mathrm{MTC}_{\mathrm{t}}+\mathrm{MTR}_{\mathrm{t}}
$$

\section{Produksi garmen domestik}

$$
\begin{aligned}
\text { PGD }_{\mathrm{t}}=\mathrm{g}_{0}+ & \mathrm{g}_{1}\left(\mathrm{HGWR}_{\mathrm{t}-1} / \mathrm{HGDR}_{\mathrm{t}-1}\right)+\mathrm{g}_{2}\left(\mathrm{HTDR}_{\mathrm{t}}-\mathrm{HTDR}_{\mathrm{t}-1}\right)+\mathrm{g}_{3} \mathrm{HCWR}_{\mathrm{t}-1}+ \\
& \mathrm{g}_{4}\left(\mathrm{IRR}_{\mathrm{t}} \mathrm{IRR}_{\mathrm{t}-1}\right)+\mathrm{g}_{5} \mathrm{UTKGR}_{\mathrm{t}-1}+\mathrm{g}_{6} \mathrm{BBMR}_{\mathrm{t}}+ \\
& \mathrm{g}_{7} \mathrm{~T}+\mathrm{g}_{8} \mathrm{PGD}_{\mathrm{t}-1}+\mathrm{U}_{7} \ldots \ldots \ldots \ldots \ldots \ldots \ldots \ldots \ldots \ldots \ldots \ldots \ldots \ldots \ldots \ldots \ldots \ldots \ldots \ldots \ldots \ldots \ldots \ldots \ldots \ldots \ldots \ldots \ldots \ldots \ldots \ldots \ldots \ldots \ldots \ldots \ldots
\end{aligned}
$$

Tanda parameter dugaan yang diharapkan dalam persamaan adalah:

$\mathrm{g}_{1}, \mathrm{~g}_{7}>0 ; \mathrm{g}_{2}, \mathrm{~g}_{3}, \mathrm{~g}_{4}, \mathrm{~g}_{5}, \mathrm{~g}_{6}<0$ dan $0<\mathrm{g}_{8}<1$.

\section{Ekspor garmen Indonesia}

$$
\begin{aligned}
\text { XGI }_{t}= & h_{0}+h_{1} \text { HGWR }_{t}+h_{2}\left(\text { HTWR }_{t} / \text { HGDR }_{t-1}\right)+h_{3} \text { PGD }_{t}+ \\
& h_{4} \text { ERIR }_{t-1}+h_{5} \text { DKG }+h_{6} T+h_{7} \text { XGI }_{t-1}+\mathrm{U}_{8} \ldots \ldots \ldots \ldots \ldots . . . . .
\end{aligned}
$$


Tanda parameter dugaan yang diharapkan dalam persamaan adalah:

$\mathrm{h}_{2}, \mathrm{~h}_{5}<0, \mathrm{~h}_{1}, \mathrm{~h}_{3}, \mathrm{~h}_{4}, \mathrm{~h}_{6}>0$ dan $0<\mathrm{h}_{7}<1$.

\section{Penawaran garmen domestik}

$$
\mathrm{SGD}_{\mathrm{t}}=\mathrm{PGD}_{\mathrm{t}}+\mathrm{MGI}_{\mathrm{t}}-\mathrm{XGI}_{\mathrm{t}}
$$

13. Permintaan garmen domestik

$$
\begin{aligned}
\text { DGD }_{\mathrm{t}}=\mathrm{i}_{0}+ & \mathrm{i}_{1}\left(\text { HGWR }_{\mathrm{t}} / \text { HTWR }_{\mathrm{t}-1}\right)+\mathrm{i}_{2}\left(\mathrm{HGDR}_{\mathrm{t}} * \text { ERIR }_{\mathrm{t}}\right)+ \\
& \mathrm{i}_{3}\left(\text { GDPIR }_{\mathrm{t}} / \text { POPI }_{\mathrm{t}}\right)+\mathrm{i}_{4}\left(\text { MGI }_{\mathrm{t}}-\mathrm{MGB}_{\mathrm{t}-1}\right)+\mathrm{i}_{5} \text { DGD }_{\mathrm{t}-1}+\mathrm{U}_{9}
\end{aligned}
$$

Tanda parameter dugaan yang diharapkan dalam persamaan adalah:

$\mathrm{i}_{1}, \mathrm{i}_{2}, \mathrm{i}_{4}<0 ; \mathrm{i}_{3}>0$ dan $0<\mathrm{i}_{5}<1$.

\section{Impor garmen Indonesia}

$$
\begin{aligned}
\text { MGI }_{\mathrm{t}}= & \mathrm{j}_{0}+\mathrm{j}_{1} \text { HMGIR }_{\mathrm{t}}+\mathrm{j}_{2}\left(\text { HGWR }_{\mathrm{t}} \text { HGWR }_{\mathrm{t}-1}\right)+\mathrm{j}_{3} \text { TFG }_{\mathrm{t}}+\mathrm{j}_{4} \text { PGD }_{\mathrm{t}-1}+ \\
& \mathrm{j}_{5} \text { ERIR }_{\mathrm{t}}+\mathrm{j}_{6}\left(\text { GDPIR }_{\mathrm{t}} \text { POPI }_{\mathrm{t}}\right)+\mathrm{j}_{7} \mathrm{MGI}_{\mathrm{t}-1}+\mathrm{U}_{10} \ldots \ldots \ldots \ldots \ldots \ldots \ldots \ldots \ldots \ldots \ldots \ldots
\end{aligned}
$$

Tanda parameter dugaan yang diharapkan dalam persamaan adalah:

$\mathrm{j}_{1}, \mathrm{j}_{2}, \mathrm{j}_{3}, \mathrm{j}_{4}, \mathrm{j}_{5}<0 ; \mathrm{j}_{6}>0$ dan $0<\mathrm{j}_{7}<1$.

\section{Harga garmen domestik}

$$
\begin{aligned}
\operatorname{HGDR}_{\mathrm{t}}= & \mathrm{k}_{0}+\mathrm{k}_{1}\left(\mathrm{DGD}_{\mathrm{t}} / \mathrm{DGD}_{\mathrm{t}-1}\right)+\mathrm{k}_{2}\left(\mathrm{HTWR}_{\mathrm{t}}-\mathrm{HTWR}_{\mathrm{t}-1}\right)+ \\
& \mathrm{k}_{3}\left(\mathrm{HTWR}_{\mathrm{t}}-\mathrm{HTWR}_{\mathrm{t}-1}\right)+\mathrm{k}_{4}\left(\mathrm{HGWR}_{\mathrm{t}-1} / \mathrm{HTWR}_{\mathrm{t}}\right)+\mathrm{k}_{5} \mathrm{~T} \\
& \mathrm{k}_{6} \mathrm{HGDR}_{\mathrm{t}-1}+\mathrm{U}_{11} \ldots \ldots \ldots \ldots \ldots \ldots \ldots \ldots \ldots \ldots \ldots \ldots \ldots \ldots \ldots \ldots \ldots \ldots \ldots \ldots \ldots \ldots \ldots \ldots \ldots \ldots \ldots \ldots \ldots \ldots \ldots \ldots \ldots
\end{aligned}
$$

Tanda parameter dugaan yang diharapkan dalam persamaan adalah:

$\mathrm{k}_{1}, \mathrm{k}_{2}, \mathrm{k}_{3}, \mathrm{k}_{4}>0 ; \mathrm{k}_{5}<0$ dan $0<\mathrm{k}_{6}<1$.

\section{Harga garmen dunia}

$\mathrm{HGWR}_{\mathrm{t}}=1_{0}+1_{1} \mathrm{XGW}_{\mathrm{t}}+1_{2} \mathrm{MGW}_{\mathrm{t}-1}+1_{3} \mathrm{HGWR}_{\mathrm{t}-1}+\mathrm{U}_{12}$

Tanda parameter dugaan yang diharapkan dalam persamaan adalah:

$$
1_{1}<0 ; 1_{2}>0 \text { dan } 0<1_{3}<1 \text {. }
$$

\section{Ekspor garmen dunia}

$$
\mathrm{XGW}_{\mathrm{t}}=\mathrm{XGI}_{\mathrm{t}}+\mathrm{XGG}_{\mathrm{t}}+\mathrm{XGC}_{\mathrm{t}}+\mathrm{XGT}_{\mathrm{t}}+\mathrm{XGR}_{\mathrm{t}}
$$

18. Impor garmen dunia

$$
\mathrm{MGW}_{\mathrm{t}}=\mathrm{MGI}_{\mathrm{t}}+\mathrm{MGG}_{\mathrm{t}}+\mathrm{MGA}_{\mathrm{t}}+\mathrm{MGJ}_{\mathrm{t}}+\mathrm{MGR}_{\mathrm{t}}
$$




\subsection{Tinjauan Empiris Tekstil dan Produk Tekstil}

\subsubsection{Tinjauan Empiris Tekstil dan Produk Tekstil di Indonesia}

Penelitian Pracoyo (1995) berkaitan dengan ekspor industri tekstil yang menggunakan data time series tahun 1983-1992 dan metode pendugaan Two Stage Least Squares (2SLS). Pracoyo mengadopsi model permintaan dan penawaran ekspor yang telah dilakukan oleh Muscatelli, Srinivasan, dan Vines (1992). Hasil adaptasinya bahwa penawaran ekspor tekstil Indonesia dipengaruhi oleh harga tekstil, biaya bahan baku, upah, tarif, dan teknologi. Sedangkan dari sisi permintaan ekspor tekstil dipengaruhi oleh harga tekstil, harga tekstil dunia, harga barang substitusi (harga wool dunia), pendapatan negara lain, dan selera konsumen. Selain itu disimpulkan bahwa (1) penurunan tarif akan mendorong perdagangan dunia lebih kompetitif. Pengurangan tarif sebesar 30 persen akan mendorong perdagangan dunia lebih kompetitif, (2) pemberian upah sebesar 1 persen akan mengurangi kuantitas yang ditawarkan 4,5 persen, hal ini terjadi karena upah termasuk komponen biaya dalam produksi, dan (3) perubahan teknologi, yang ditunjukkan peubah trend, mendorong produksi tekstil menjadi lebih efisien.

Penelitian menggunakan metode pendugaan Ordinary Least Squares (OLS) dilakukan oleh Wintala (1999). Kesimpulan yang dapat diambil dari analisis faktor-faktor yang mempengaruhi ekspor tekstil Indonesia ke Amerika Serikat, Inggris, dan Jepang pada tahun 1978-1997, bahwa trend volume ekspor tekstil Indonesia ke Amerika Serikat, Inggris, dan Jepang adalah positif dan signifikan secara statistik. Devaluasi Rupiah, kenaikan cadangan devisa, peningkatan jumlah penduduk, dan indeks harga sandang cenderung menaikkan volume ekspor tekstil Indonesia.

Penelitian Istojo (2002) menganalisis struktur industri TPT Indonesia terhadap World Trade Organization (WTO) tahun 2005. Metode yang digunakan adalah deskripsi karakteristik industri, five forces model, driving forces, dan key success factor. Hasil yang diperoleh bahwa ketergantungan industri TPT adalah tinggi terhadap pemasok dan pembeli serta persaingan yang ketat antara perusahaan dalam industri TPT Indonesia. Pemberlakuan WTO tahun 2005 menambah persaingan dan perebutan pasar di dalam dan luar negeri. Pemberlakuan WTO juga akan merubah struktur industri TPT menjadi mass customization yang cenderung pada non price factor dan secara penuh didukung oleh prinsip quick response dan just in time stock. Disebutkan pula bahwa perusahaan-perusahaan dalam industri TPT harus dapat melakukan banyak inovasi manufacture sehingga diferensiasi produk akan meningkat.

Agustineu (2004) menganalisis faktor-faktor yang mempengaruhi ouput industri tekstil di Jawa Barat dengan menggunakan model Cobb Douglas tahun 1980-2001. Hasilnya ternyata 
modal, bahan baku, dan bahan bakar memberikan pengaruh positif terhadap peningkatan output industri tekstil di Jawa Barat. Faktor tenaga kerja memberikan pengaruh yang berkebalikan dengan faktor-faktor yang pertama disebutkan. Industri tekstil di Jawa Barat berada pada kondisi increasing return to scale.

\subsubsection{Tinjauan Penelitian Tekstil dan Produk Tekstil Dunia}

Mlachila dan Yongzheng (2004) menggunakan General Trade Analysis Project (GTAP) untuk menganalisis berakhirnya kuota tekstil dengan studi kasus di Bangladesh. Terdapat tiga faktor yang mempengaruhi kinerja ekspor tekstil dan pakaian jadi Bangladesh pada tahun 1990an, yaitu upah yang rendah, aliran masuk Foreign Direct Investment (FDI), dan kuota yang diberlakukan di negara pesaing. Bangladesh menghadapi masalah yang serius dengan daya saing setelah sistem kuota berakhir, karena infrastruktur yang lemah dan berbagai iklim makro yang tidak mendukung. Hasil simulasi menunjukkan bahwa ekspor Bangladesh akan menurun setelah penghapusan kuota dan berpengaruh terhadap Balance of Payment (BOP).

WTO (2004) dengan menggunakan GTAP menjelaskan kondisi industri TPT global setelah berakhirnya ATC. Cina dan India merupakan negara-negara yang akan mendominasi pasar TPT Uni Eropa, Amerika Serikat, dan Kanada setelah sistem kuota berakhir. Bahkan Cina diprediksikan akan mengambil pangsa pasar TPT dunia hingga 50 persen. Selain itu, spesialisasi vertikal dalam supply chain TPT adalah sangat penting dan bagi negara-negara yang mempunyai kedekatan secara geografis akan banyak diuntungkan dengan perjanjian bilateral dan tarif yang lebih rendah. Temuan yang penting bagi TPT Indonesia adalah perubahan pangsa pasar TPT di pasar Uni Eropa dan Amerika Serikat. Di pasar Uni Eropa, setelah kuota berakhir Indonesia akan mendapatkan kenaikan pangsa pasar sebesar 1 persen (dari 4 persen menjadi 5 persen) untuk pasar garmen. Sedangkan untuk pasar tekstil, Indonesia mengalami stagnan (dari 3 persen menjadi 3 persen). Berbeda yang terjadi di pasar Amerika Serikat, tekstil Indonesia akan mengalami stagnan (dari 3 persen menjadi 3 persen). Penurunan terjadi untuk komoditas garmen di pasar Amerika Serikat (dari 4 persen menjadi 2 persen).

Dari berbagai telaah penelitian tentang industri TPT yang telah dilakukan, secara umum memberikan gambaran tentang perkembangan ekspor TPT dan faktor-faktor yang mempengaruhinya, baik di tingkat nasional maupun internasional. Selain itu, banyak penelitian yang melakukan prediksi terhadap perkembangan industri TPT pasca kuota tahun 2005. Namun demikian, tetap ada bagian yang belum dielaborasi secara mendalam oleh peneliti-peneliti sebelumnya. Keterkaitan antara pasar Indonesia dan pasar dunia berperan penting dalam menelaah perkembangan industri TPT Indonesia. Penelitian agregat dan deskriptif industri TPT 
cenderung menghasilkan kesimpulan yang tidak spesifik, sedangkan penelitian dengan skala mikro juga akan menghasilkan kesimpulan yang tidak dapat digeneralisasi. Oleh sebab itu, pada kesempatan ini dianalisis perkembangan industri TPT secara holistik, baik industri tekstil dan maupun industri garmen, dengan mengaitkan industri TPT secara simultan melalui peubahpeubah ekonomi, termasuk kebijakan moneter dan fiskal.

\section{METODOLOGI}

Alat analisis utama yang digunakan adalah ekonometrika time series, yang berguna untuk menganalisis faktor-faktor melalui nilai (sign dan size) parameter penduga setiap persamaan perilaku dan prospek perkembangan industri TPT Indonesia melalui simulasi peramalan. Selain itu, seluruh persamaan struktural telah mengalami respsesifikasi model secara trial and error sehingga pada akhirnya diperoleh persamaan-persamaan yang sesuai dengan syarat keharusan dan kecukupan dalam menyusun persamaan simultan tanpa mengabaikan asumsi-asumsi dasar persamaan regresi (multikolinearitas, homoskedastisitas, dan autokorelasi).

\subsection{Identifikasi Model dan Metode Pendugaan}

Menurut order condition, persamaan dapat diidentifikasi jika jumlah peubah yang tercakup dalam persamaan lebih besar atau sama dengan jumlah seluruh peubah endogen dikurangi satu. Formula identifikasi model struktural menurut order condition (Koutsoyiannis, 1978) adalah sebagai berikut:

$(K-M)>(G-1)$

dimana:

$\mathrm{K}=$ Total peubah dalam model (peubah endogen dan predetermined) .

$\mathrm{M}=$ Jumlah peubah endogen dan eksogen dalam satu persamaan.

$\mathrm{G}=$ Total persamaan dalam model.

Jika suatu persamaan dalam model menunjukkan kondisi $(K-M)>(G-1)$ maka persamaan dinyatakan over identified, jika $(K-M)=(G-1)$ maka persamaan dinyatakan exactly identified, dan jika (K - M) < (G - 1) maka persamaan dinyatakan under identified. Model struktural dalam penelitian ini terdapat 30 persamaan, terdiri dari 24 persamaan perilaku (behavioral) dan 6 persamaan identitas. Jumlah peubah endogen (G) adalah 24 dan 80 peubah predeterminan. Jumlah seluruh peubah yang tercakup dalam model (K) adalah 104. Mengikuti 
formula identifikasi model dengan kriteria order condition, maka setiap persamaan adalah over identified.

Jika persamaan dalam model struktural semuanya over identified maka persamaan ini dapat diduga dengan metode Limited Information Maximum Likelihood (LIML), Full Information Maximum Likelihood (FIML), Two Stage Least Squares (2SLS) atau Three Stage Least Squares (3SLS). Metode yang digunakan di dalam penelitian ini untuk menduga parameter dugaan struktural adalah 2SLS. Metode 2SLS dibentuk dengan asumsi (1) syarat gangguan harus memenuhi asumsi stokastik dengan nol, varian konstan dan kovarian sama dengan nol, (2) spesifikasi model struktural adalah tepat sekali sejauh menyangkut peubah predetermined, (3) jumlah pengamatan sampel adalah lebih besar dari jumlah peubah predetermined dalam model, dan (4) peubah penjelas tidak mengalami kolinearitas sempurna. Dengan memperhatikan asumsi tersebut maka DW statistik (Durbin Watson) tidak valid untuk menduga persamaan struktural dari model persamaan simultan, terutama dengan adanya peubah endogen bedakala.

Pengolahan data untuk mengestimasi model ekonomi dilakukan dengan menggunakan program software komputer SAS versi 6.12. Untuk menguji peubah penjelas secara bersamasama digunakan uji statistik $F$, sedangkan untuk menguji peubah penjelas secara individual digunakan uji statistik t.

Validasi model ekonomi bertujuan untuk manganalisis sejauhmana model tersebut dapat mewakili dunia nyata. Adapun kriteria statistik validasi pendugaan model ekonomi yang digunakan adalah Root Means Square Error(RMSE), Root Means Square Percent Error(RMSPE), dan Theil's Inequality Coefficient'(U-theil).

Statistik RMSPE digunakan untuk mengukur seberapa jauh nilai-nilai peubah endogen hasil pendugaan menyimpang dari alur nilai-nilai aktualnya dalam ukuran relatif (persen). Sedangkan nilai statistik U-theil untuk mengetahui kemampuan model menganalisis simulasi peramalan. Nilai U-theil berkisar antara 1 dan 0 . Jika U-theil $=0$ maka pendugaan model sempurna, jika U-theil = 1 maka pendugaan model naif. Untuk melihat keeratan arah (slope) antara aktual dengan hasil yang disimulasi dilihat dari nilai koefisien determinasi $\left(R^{2}\right)$. Pada dasarnya makin kecil nilai RMSPE dan U-theil dan makin besar nilai koefisien determinasi, maka pendugaan model semakin baik. Dengan model yang sudah valid,maka simulasi kebijakan dapat di lakukan.

Kebijakan-kebijakan yang disimulasikan untuk peramalan (ex-ante) tahun 2007-2012 yaitu, penurunan suku bunga bank di Indonesia, penyesuaian nilai tukar Rupiah/US\$, kenaikan biaya produksi industri TPT melalui upah dan harga BBM, kenaikan PDB Indonesia, kenaikan 
jumlah penduduk Indonesia, kenaikan PDB Amerika Serikat, kenaikan PDB Cina, dan penghapusan tarif TPT, serta kombinasinya.

\subsection{Sumber dan Jenis Data}

Jenis data yang digunakan dalam model ekonometrika adalah data sekunder time series tahun 1980-2006. Data bersumber dari publikasi resmi, yaitu Asosiasi Pertekstilan Indonesia (API), Badan Pusat Statistik (BPS), United Nations Conference on Trade and Development (UNCTAD), United Nation (UN), International Monetary Fund (IMF), WTO, Kementrian Perdagangan, Kementrian Perindustrian, harian terbitan Jakarta, dan internet.

Seluruh data-data yang bersatuan Rupiah dideflasi menggunakan Indeks Harga Konsumen (IHK) Indonesia tahun 2000 (2000=100) dan peubah yang bersatuan US\$ dideflasi menggunakan proksi IHK Amerika Serikat tahun 2000 (2000=100). Hal ini dilakukan untuk menghilangkan efek dari inflasi.

\section{HASIL DAN PEMBAHASAN}

\subsection{Struktur Model Ekonomi Tekstil dan Produk Tekstil Indonesia}

\section{a. Produksi Tekstil Indonesia}

Keragaan produksi tekstil Indonesia dapat dijelaskan sebesar 98 oleh lag harga tekstil Indonesia, lag harga kapas dunia, suku bunga bank, lag upah tenaga kerja tekstil, lag harga BBM, tren waktu, dan lag produksi tekstil Indonesia. Semua tanda parameter dugaan sesuai dengan harapan dan secara statistik semua peubah tersebut berpengaruh nyata.

Koefisien parameter dugaan lag harga tekstil Indonesia bertanda positif dan sebesar 0,514. Hal ini berarti jika terjadi peningkatan lag harga tekstil Indonesia sebesar 10 US $\$$ per ton, maka produksi tekstil Indonesia akan naik sebesar 5.140 ribu ton, ceteris paribus. Peningkatan produksi tekstil Indonesia yang searah dengan peningkatan harga tekstil Indonesia menunjukkan bahwa harga tekstil Indonesia merupakan sinyal ekonomi bagi produsen tekstil dalam memproduksi tekstil di pasar Indonesia.

Bahan baku utama tekstil adalah serat tekstil dan memiliki keunggulan yang belum dapat digantikan sepenuhnya oleh bahan baku non kapas. Salah satunya adalah mudah menyerap keringat atau bersifat higroskopis. Oleh sebab itu perubahan harga kapas dunia mempengaruhi perubahan produksi tekstil Indonesia. Menurut Istojo (2002) industri tekstil Indonesia sangat tergantung kepada pemasok dan pembeli. Lebih dari 85 persen kebutuhan kapas untuk industri 
tekstil Indonesia diimpor dari Australia, Amerika Serikat, Cina, India, Pakistan, Tanzania, dan lainnya. Hal ini karena tanaman kapas belum dapat dibudidayakan secara maksimal di dalam negeri. Di dalam penelitian ini, produksi tekstil Indonesia juga dipengaruhi secara nyata oleh lag harga kapas dunia dengan arah yang berlawanan. Apabila lag harga kapas dunia meningkat sebesar 10 US\$ per ton, maka akan menurunkan produksi tekstil Indonesia sebesar 354.812 ribu ton, ceteris paribus. Dalam jangka pendek maupun jangka panjang produksi tekstil Indonesia sangat responsif terhadap lag harga kapas dunia.

Suku bunga bank diproksi dengan suku bunga bank untuk kegiatan investasi. Suku bunga bank memberikan kontribusi berlawanan arah dengan produksi tekstil Indonesia. Jika suku bunga bank dinaikkan melalui kebijakan moneter sebesar 1 persen, ceteris paribus, maka tindakan itu akan menurunkan produksi tekstil Indonesia sebesar 2.410 ribu ton. Keadaan tersebut menurunkan insentif bagi produsen sehingga mengurangi produksi tekstil Indonesia sebesar 0,053 persen dalam jangka pendek dan 0,772 persen dalam jangka panjang.

Industri TPT menyerap banyak tenaga kerja sehingga upah tenaga kerja menjadi salah satu komponen biaya produksi yang penting dalam keberlanjutan proses produksi. Upah tenaga kerja di sektor industri tekstil berpengaruh nyata terhadap produksi tekstil Indonesia dengan arah negatif. Jika besaran upah tenaga kerja di sektor industri tekstil dinaikkan sebesar Rp. 1 000000 per kapita per tahun, maka akan menurunkan produksi tekstil Indonesia sebesar 0,110 ribu ton, ceteris paribus. Respon produksi tekstil Indonesia terhadap upah tenaga kerja di sektor industri tekstil adalah inelastis dalam jangka pendek dan elastis dalam jangka panjang. Sama seperti yang dilakukan oleh Pracoyo (1995) bahwa peubah upah tenaga kerja berpengaruh nyata secara statistik pada produksi tekstil Indonesia.

Selain upah tenaga kerja, harga BBM (terutama solar dan minyak bakar) juga berkontribusi dalam biaya produksi di sektor industri tekstil. Harga BBM berhubungan negatif dengan produksi tekstil Indonesia dan berpengaruh signifikan secara statistik. Jika harga BBM meningkat sebesar Rp. 10 per liter, maka akan menurunkan produksi tekstil Indonesia sebesar 1.444 ribu ton, ceteris paribus. Dalam jangka pendek dan jangka panjang, produksi tekstil Indonesia kurang responsif terhadap harga BBM.

Kecenderungan waktu menunjukkan terjadinya peningkatan produksi tekstil Indonesia sebesar 51.830 ribu ton. Hal ini sangat terkait dengan industri garmen yang sangat membutuhkan ouput industri tekstil sebagai bahan bakunya.

Lag produksi tekstil Indonesia juga menjadi informasi dasar bagi produsen untuk berproduksi di tahun berikutnya. Apabila lag produksi tekstil mengalami kenaikan sebesar 1000 ton, maka pada tahun berikutnya produknya akan naik sebesar 0,720 ribu ton, ceteris paribus. 


\section{b. Ekspor Tekstil Indonesia}

Persamaan ekspor tekstil Indonesia mempunyai nilai koefisien determinasi yang tinggi, yaitu 0,961, menunjukkan tingginya kemampuan peubah-peubah penjelas dalam menjelaskan perilaku ekspor tekstil Indonesia. Semua peubah penjelas mempunyai tanda parameter dugaan sesuai harapan. Namun demikian, tidak semua peubah mempunyai pengaruh nyata terhadap ekspor tekstil Indonesia. Peubah yang berpengaruh nyata adalah perubahan harga tekstil Indonesia, dummy integrasi perdagangan TPT dunia, dan lag ekspor tekstil.

Harga tekstil Indonesia yang meningkat akan menjadi insentif bagi produsen untuk berproduksi. Jika perubahan harga tekstil Indonesia naik sebesar US\$10 per ton, maka akan menurunkan ekspor tekstil Indonesia sebesar 5.854 ribu ton, ceteris paribus. Dalam jangka pendek, respon ekspor tekstil Indonesia terhadap perubahan harga tekstil Indonesia adalah inelastis dan menjadi elastis dalam jangka panjang.

Perdagangan TPT dunia mengalami perubahan signifikan dari tahun 1950an hingga tahun 2005. Tahap pengintegrasian perdagangan TPT sesuai ketentuan GATT dimulai tahun 1995 hingga tahun 2005. Proses tersebut mengurangi jumlah dan jenis TPT kuota impor dari negara pengimpor, seperti Amerika Serikat, Kanada, Uni Eropa, Finlandia, Norwegia, dan Turki. Keadaan ini berdampak pada ekspor tekstil Indonesia. Di dalam penelitian ini dummy pengintegrasian perdagangan TPT berpengaruh nyata terhadap ekspor tekstil Indonesia. Proses pengintegrasian perdagangan TPT selama 10 tahun menurunkan ekspor tekstil Indonesia hingga 134.367 ribu ton.

Lag ekspor tekstil Indonesia juga berpengaruh secara nyata terhadap ekspor tekstil Indonesia pada tahun berikutnya. Hal ini menunjukkan bahwa ekspor tekstil Indonesia memerlukan waktu yang relatif lambat untuk menyesuaikan kembali pada tingkat keseimbangan, atau dengan kata lain ekspor tekstil Indonesia relatif tidak stabil.

\section{c. Penawaran Tekstil Indonesia}

Total penawaran tekstil Indonesia merupakan penjumlahan dari produksi tekstil, impor tekstil, dan tekstil yang diekspor Indonesia. Berdasarkan hubungan identitas tersebut, maka setiap perubahan dalam produksi tekstil, impor tekstil, dan ekspor tekstil yang ditimbulkan akibat intervensi pemerintah, antara lain melalui instrumen kebijakan moneter dan fiskal, akan mempengaruhi jumlah tekstil yang tersedia di pasar Indonesia. Besaran perubahan penawaran tekstil Indonesia tergantung pada nilai elastisitas produksi tekstil, impor tekstil, dan juga ekspor tekstil Indonesia, baik secara langsung maupun tidak langsung. 


\section{d. Harga Tekstil Indonesia}

Nilai koefisien determinasi persamaan harga tekstil Indonesia sebesar yaitu 0,833. Hal tersebut mengindikasikan tingginya kemampuan peubah-peubah penjelas dalam menjelaskan perilaku harga tekstil Indonesia. Tanda parameter dugaan peubah dalam persamaan struktural juga telah sesuai dengan harapan dan peubah yang berpengaruh nyata terhadap harga tekstil Indonesia adalah perubahan harga garmen Indonesia, dan lag harga tekstil Indonesia.

Perubahan harga gamen Indonesia berpengaruh nyata terhadap harga tekstil Indonesia dengan arah yang positif. Jika perubahan harga garmen Indonesia naik sebesar US\$100 per ton, maka akan menstimulasi kenaikan harga tekstil Indonesia sebesar US\$ 0,819 per ton, ceteris paribus. Responsinya dalam jangka pendek dan jangka panjang adalah inelastis, hal ini menunjukkan bahwa harga tekstil Indonesia kurang responsif terhadap perubahan harga garmen Indonesia.

Selain perubahan harga garmen Indonesia, lag harga tekstil Indonesia juga berpengaruh sangat nyata. Hal ini mengindikasikan bila harga tekstil Indonesia memerlukan waktu yang relatif lambat untuk menyesuaikan kembali pada tingkat keseimbangan, atau dengan kata lain harga tekstil Indonesia relatif tidak stabil. Jika lag harga tekstil Indonesia naik sebesar US\$10 per ton, maka akan meningkatkan harga tekstil Indonesia tahun berikutnya sebesar US $\$ 6.889$ per ton, ceteris paribus.

\section{e. Permintaan Tekstil Indonesia}

Persamaan permintaan tekstil Indonesia mempunyai nilai koefisien determinasi cukup tinggi, yaitu 0,819. Keadaan ini menggambarkan tingginya kemampuan peubah-peubah penjelas dalam menjelaskan perilaku permintaan tekstil Indonesia. Permintaan tekstil Indonesia dijelaskan oleh perubahan harga tekstil Indonesia, lag harga garmen Indonesia, lag upah tenaga kerja sektor industri tekstil, perubahan suku bunga bank, tren waktu, dan lag permintaan tekstil Indonesia. Tanda parameter dugaan semuanya sesuai dengan harapan. Lag harga garmen Indonesia, lag upah tenaga kerja sektor industri tekstil, dan lag permintaan tekstik Indonesia berpengaruh nyata terhadap permintaan tekstil Indonesia.

Lag harga garmen Indonesia mempunyai hubungan yang berlawanan dengan permintaan tekstil Indonesia. Jika lag harga garmen naik sebesar US $\$ 10$ per ton, maka permintaan tekstil Indonesia akan turun sebesar 0,270 ribu ton, ceteris paribus. Selain itu permintaan tekstil Indonesia kurang responsif terhadap perubahan lag harga garmen Indonesia, baik di dalam jangka pendek maupun jangka panjang. Permintaan tekstil Indonesia merupakan cerminan 
permintaan tekstil oleh industri tekstil itu sendiri dan pada akhirnya output industri tekstil akan digunakan sebagai input oleh industri garmen.

Lag upah tenaga kerja di sektor tekstil berkontribusi mempengaruhi perubahan tekstil Indonesia yang diminta. Jika lag upah tenaga kerja di sektor industri tekstil naik 1 persen, maka akan menurunkan permintaan tekstil Indonesia sebesar 0,715 persen dalam jangka pendek dan 1.856 persen dalam jangka panjang. Permintaan tekstil merupakan derived demand untuk industri garmen. Informasi lag permintaan tekstil Indonesia berperan penting untuk memperkirakan permintaan tekstil Indonesia pada tahun berikutnya. Jika lag permintaan tekstil Indonesia naik sebesar 1000 ton, maka ada kecenderungan juga akan menaikan permintaan tekstil Indonesia pada tahun berikutnya sebesar 0,615 ribu ton, ceteris paribus.

\section{f. Impor Tekstil Indonesia}

Berdasarkan hasil signifikansi parameter dugaan, hanya lag impor tekstil Indonesia yang berpengaruh secara nyata terhadap impor tekstil Indonesia pada tahun berikutnya. Hal ini menunjukkan bahwa impor tekstil Indonesia memerlukan waktu yang relatif lambat untuk menyesuaikan kembali pada tingkat keseimbangan.

\section{g. Produksi Garmen Indonesia}

Keragaan produksi garmen Indonesia dapat dijelaskan sebesar 0,939 oleh peubah-peubah penjelasnya. Tanda parameter dugaan peubah dalam persamaan struktural juga telah sesuai dengan harapan. Peubah yang berpengaruh signifikan adalah ag upah tenaga kerja garmen, tren waktu, dan ag produksi garmen.

Selain industri tekstil menyerap banyak tenaga kerja, sektor industri garmen juga demikian. Terdapat bagian dalam proses produksi garmen, seperti menjahit, yang tidak bisa digantikan sepenuhnya oleh mesin. Penggunaan tenaga kerja yang banyak akan berpengaruh terhadap biaya produksi. Lag upah tenaga kerja garmen dalam penelitian ini berbeda nyata secara statistik. Jika ada kenaikan lag upah tenaga kerja garmen sebesar Rp. 1000000 per kapita per tahun, maka akan menurunkan produksi garmen Indonesia sebesar 0,055 ribu ton, ceteris paribus. Dalam jangka pendek, produksi garmen Indonesia kurang responsif jika dibandingkan dalam jangka panjang.

Di samping lag upah tenaga kerja garmen, tren waktu juga berpengaruh sangat nyata terhadap produksi garmen Indonesia. Garmen adalah produk yang sangat berkaitan dengan tren mode dan berubah sesuai perkembangan jaman. Berdasarkan kecenderungan waktu, 
produksi garmen Indonesia mengalami kenaikan 26.869 ribu ton. Selain itu lag produksi garmen menjadi informasi memproduksi garmen tahun berikutnya. Jika lag produksi garmen Indonesia naik sebesar 1000 ton, maka produksi garmen Indonesia tahun berikutnya meningkat sebesar 0,453 ribu ton, ceteris paribus.

\section{h. Ekspor Garmen Indonesia}

Keragaan ekspor garmen Indonesia sebesar 0,952 dapat dijelaskan oleh peubah-peubah penjelasnya. Tanda parameter dugaan peubah dalam persamaan struktural juga telah sesuai dengan harapan. Ekspor garmen Indonesia dijelaskan oleh rasio lag harga garmen dunia dengan harga tekstil dunia, harga garmen Indonesia, rasio produksi garmen Indonesia dengan lag produksi garmen Indonesia, lag nilai tukar Rupiah terhadap US\$, dummy integrasi perdagangan TPT dunia, dan lag ekspor garmen Indonesia. Dari enam peubah tersebut, hanya lag nilai tukar Rupiah terhadap US\$ dan lag ekspor garmen Indonesia yang berpengaruh nyata.

Eksportasi garmen berkaitan dengan nilai tukar Rupiah terhadap US\$. Nilai tukar Rupiah yang terdepresiasi akan meningkatkan daya saing garmen Indonesia. Lag nilai tukar Rupiah terhadap US\$ berpengaruh sangat nyata dengan elastisitas jangka pendek sebesar 0,310 dan jangka panjang sebesar 1,353. Artinya bila lag nilai tukar Rupiah terhadap US\$ depresiasi sebesar 10 persen, maka ekspor garmen Indonesia akan meningkat sebesar 3,10 persen dalam jangka pendek dan 13,530 persen dalam jangka panjang atau elastis, ceteris paribus.

Koefisien lag ekspor garmen Indonesia mempunyai hasil parameter dugaan bertanda positif sebesar 0,771. Artinya jika lag ekspor garmen Indonesia bertambah 1000 ton, maka ekspor garmen Indonesia tahun berikutnya akan meningkat sebesar 0,771 ribu ton, ceteris paribus.

\section{i. Penawaran Garmen Indonesia}

Total penawaran garmen Indonesia merupakan persamaan identitas dari produksi garmen Indonesia, impor garmen Indonesia, dan ekspor garmen Indonesia. Besaran perubahan penawaran garmen Indonesia tergantung pada nilai elastisitas produksi garmen, impor garmen, dan juga ekspor garmen Indonesia, baik secara langsung maupun tidak langsung.

\section{j. Harga Garmen Indonesia}

Persamaan harga garmen Indonesia mempunyai nilai koefisien determinasi yang tinggi, yaitu 0,889 . Hal ini menunjukkan tingginya kemampuan peubah-peubah penjelas menjelaskan 
perilaku harga garmen Indonesia. Tanda parameter dugaan peubah dalam persamaan juga telah sesuai dengan harapan. Harga garmen Indonesia dapat dijelaskan secara bersama-sama oleh rasio permintaan garmen Indonesia dengan lag produksi garmen Indonesia, lag harga garmen dunia, perubahan harga teksil dunia, dan lag harga garmen Indonesia.

Satu-satunya peubah yang berpengaruh nyata adalah lag harga garmen Indonesia. Informasi lag harga menjadi hal penting untuk menetapkan harga pada tahun berikutnya. Lag harga garmen Indonesia ternyata sangat berpengaruh nyata dimana koefisien lag harga garmen Indonesia bertanda positif sebesar 0,861. Artinya jika lag harga garmen Indonesia naik sebesar 1000 ton, maka harga garmen Indonesia tahun berikutnya akan meningkat sebesar 0,8261 ribu ton, ceteris paribus.

\section{k. Permintaan Garmen Indonesia}

Keragaan permintaan garmen Indonesia dijelaskan secara bersama-sama oleh harga garmen dunia, perubahan harga tekstil Indonesia, PDB per kapita Indonesia, perubahan impor garmen bekas Indonesia, dummy integrasi perdagangan TPT dunia, dan lag permintaan garmen Indonesia. Terdapat tiga dari lima peubah yang berpengaruh secara nyata terhadap perubahan permintaan garmen Indonesia.

Harga adalah faktor penting yang mempengaruhi pergerakan permintaan, begitu pula dari hasil penelitian ini. Harga garmen Indonesia berpengaruh nyata secara statistik dengan hubungan yang negatif. Sedangkan berdasarkan elastisitasnya, maka elastisitas jangka pendek sebesar 0,387 persen dan jangka panjang sebesar 0,553 persen. Hal ini dapat diartikan secara khusus, bahwa apabila ada kenaikan harga garmen Indonesia sebesar US\$10 per ton, maka akan menurunkan permintaan garmen Indonesia sebesar 3.870 ribu ton dalam jangka pendek dan sebesar 5.530 ribu ton dalam jangka panjang, ceteris paribus.

PDB per kapita Indonesia juga berpengaruh nyata dengan hubungan yang searah dengan perubahan permintaan garmen Indonesia. Bila PDB per kapita Indonesia meningkat sebesar Rp. 1 miliar, maka keadaan tersebut akan menstimulasi peningkatan permintaan garmen Indonesia sebesar 0,011 ribu ton, ceteris paribus. Responsi permintaan garmen Indonesia terhadap PDB per kapita Indonesia adalah inelastis, baik dalam jangka pendek maupun jangka panjang.

Kebijakan kuota impor TPT bersifat diskriminasi. Pasar-pasar tradisional, seperti Amerika Serikat, Kanada, Uni Eropa, Finlandia, Norwegia, dan Turki membatasi jumlah impor yang berasal dari Indonesia. Berdasarkan hasil penelitian, disebutkan bahwa pada saat integrasi perdagangan 
TPT dunia diterapkan, maka akan menaikan permintaan garmen Indonesia sebesar 66.548 ribu ton, ceteris paribus. Selain itu lag permintaan garmen Indonesia juga berpengaruh nyata terhadap permintaan garmen Indonesia tahun berikutnya. Jika lag permintaan garmen Indonesia naik sebesar 1000 ton, maka akan menaikkan permintaan garmen Indonesia tahun berikutnya sebesar 0,300 ribu ton, ceteris paribus.

\section{Impor Garmen Indonesia}

Impor garmen Indonesia dijelaskan oleh harga impor garmen Indonesia (dalam Rupiah), perubahan harga garmen dunia, lag tarif impor garmen, lag produksi garmen Indonesia, lag jumlah penduduk Indonesia, rasio PDB Indonesia dengan lag PDB Indonesia, dan lag impor garmen Indonesia. Peubah yang berpengaruh nyata adalah perubahan harga garmen dunia, lag tarif impor garmen, lag produksi garmen Indonesia, dan lag impor garmen Indonesia.

Koefisien parameter dugaan perubahan harga garmen dunia adalah sebesar 0,006 dengan arah yang berlawanan. Artinya jika perubahan harga garmen dunia meningkat US\$10 per ton, maka impor garmen Indonesia akan menurun sebesar 0,064 ribu ton, ceteris paribus. Sedangkan responsi impor garmen Indonesia, baik dalam jangka pendek maupun jangka panjang adalah inelastis.

Lag tarif impor garmen mempengaruhi impor garmen Indonesia dengan arah yang berlawanan. Artinya jika ada kenaikan besaran lag tarif impor garmen sebesar 1 persen, maka akan menurunkan impor garmen Indonesia sebesar 2.119 ribu ton, ceteris paribus. Baik dalam jangka pendek maupun jangka panjang, impor garmen Indonesia bersifat elastis terhadap lag tarif impor garmen.

Impor garmen Indonesia juga dipengaruhi oleh lag produksi garmen Indonesia. Jika lag produksi garmen Indonesia meningkat sebesar 1000 ton, maka impor garmen Indonesia akan menurun sebesar 0,221 ribu ton, ceteris paribus. Responsi impor garmen Indonesia terhadap lag produksi garmen Indonesia adalah elastis, baik dalam jangka pendek dan jangka panjang.

Peubah lainnya yang juga signifikan secara statistik adalah lag impor garmen Indonesia. Koefisien lag impor garmen Indonesia bertanda positif dan sebesar 0,615. Artinya jika lag impor garmen Indonesia bertambah 1000 ton, maka impor garmen Indonesia tahun berikutnya akan meningkat sebesar 0,615 ribu ton, ceteris paribus. 


\subsection{Validasi Model Ekonomi Tekstil dan Produk Tekstil Indonesia}

Dari 30 persamaan yang membentuk model, 27 persamaan memiliki nilai RMSPE di bawah 50 persen, dan 1 persamaan mempunyai nilai RMSPE antara 50 persen sampai 100 persen, serta 2 persamaan memiliki nilai RMSPE di atas 100 persen. Artinya nilai prediksi dapat mengikuti kecenderungan data historisnya dengan baik Sedangkan berdasarkan nilai U-theil, 29 persamaan memiliki nilai U-theil di bawah 0,20, dan ada 1 persamaan yang memiliki nilai U-theil di atas 0,20. Artinya bahwa simulasi model mengikuti data aktualnya dengan baik. Berdasarkan semua kriteria di atas, maka model ekonomi yang dibangun mempunyai daya ramal yang cukup valid untuk melakukan simulasi alternatif kebijakan makroekonomi melalui simulasi peramalan (ex-ante).

\subsection{Hasil Simulasi Peramalan Perkembangan Industri Tekstil dan Produk Tekstil Indonesia Tahun 2007-2012}

Pada Tabel 2 disajikan hasil simulasi kebijakan makroekonomi terhadap perkembangan TPT di Indonesia.

\begin{tabular}{|c|c|c|c|c|c|c|}
\hline \multicolumn{7}{|c|}{$\begin{array}{l}\text { Tabel } 2 . \\
\text { omi terhadap Perubahan Nilai Rata-Rata } \\
\text { gen Tahun 2007-2012 }\end{array}$} \\
\hline \multirow{2}{*}{ Peubah Endogen } & \multicolumn{6}{|c|}{ Perubahan Akibat Simulasi (\%) } \\
\hline & 1 & 2 & 3 & 4 & 5 & 6 \\
\hline Produksi Tekstil Indonesia (PTDt) & 0.0000 & 0.1936 & -25.4114 & -0.2904 & -25.4114 & 12.8267 \\
\hline Produksi Garmen Indonesia (PGDt) & -0.0049 & -0.0018 & -12.6301 & 0.0013 & -12.6298 & 1.5850 \\
\hline Permintaan Tekstil Indonesia (DTDt) & 0.0000 & -0.2822 & -73.4549 & 0.3763 & -73.4562 & 0.8467 \\
\hline Permintaan Garmen Indonesia (DGDt) & 0.0002 & 0.1286 & -0.2371 & -0.0917 & 3.2676 & 3.4647 \\
\hline Penawaran Tekstil Indonesia (STDt) & 0.0567 & -11.9239 & -34.3066 & 12.4333 & -34.1153 & 29.7464 \\
\hline Penawaran Garmen Indonesia (SGDt) & 0.0002 & -63.9076 & -18.7352 & 21.9497 & -18.5225 & 22.4123 \\
\hline Harga Tekstil Indonesia (HTDRt) & 0.0000 & 0.5344 & 1.8036 & -0.6012 & 1.7368 & -1.5364 \\
\hline Harga Garmen Indonesia (HGDRt) & 0.0000 & -0.7217 & 1.2831 & 0.4812 & 1.4435 & 0.3208 \\
\hline Ekspor Tekstil Indonesia (XTIt) & 0.0000 & 6.0591 & -8.9655 & 0.1478 & -8.9655 & 4.9261 \\
\hline Impor Tekstil Indonesia (MTIt) & -0.0021 & 0.1675 & 0.5522 & 13.7351 & 0.7630 & 13.5237 \\
\hline Harga Tekstil Dunia (HTWRt) & -0.0580 & -2.2042 & 2.9582 & 2.0302 & 2.9582 & 2.2622 \\
\hline Harga Garmen Dunia (HGWRt) & 0.0000 & -11.5351 & 2.4718 & 0.2168 & 2.4718 & -18.6904 \\
\hline Ekspor Garmen Indonesia (XGIt) & -0.0032 & 21.6763 & -4.7985 & -0.0237 & -4.8009 & 1.5617 \\
\hline Impor Garmen Indonesia (MGIt) & 0.0789 & -5.1755 & 125.1513 & 179.8909 & 126.8318 & 172.2973 \\
\hline Ekspor Tekstil Dunia (XTWt) & 0.0000 & 0.1970 & -0.2845 & 0.0031 & -0.2845 & 0.8880 \\
\hline Impor Tekstil Dunia (MTWt) & 0.0000 & 0.0304 & -0.0138 & 0.3367 & -0.0083 & 2.1058 \\
\hline Ekspor Garmen Dunia (XGWt) & 0.0000 & 0.3160 & -0.0683 & -0.0020 & -0.0683 & 0.6573 \\
\hline Impor Garmen Dunia (MGWt) & 0.0000 & 0.0072 & 0.0018 & 0.0045 & 0.0018 & 0.0573 \\
\hline \\
\hline \multicolumn{7}{|c|}{$\begin{array}{l}\text { Keterangan: } \\
\text { Simulasi } 1 \text { : Suku bunga bank turun } 5 \text { persen. }\end{array}$} \\
\hline \multicolumn{7}{|c|}{ Penyesuaian nilai tukar Rupiah=Rp. 9 000/US\$. } \\
\hline \multicolumn{7}{|c|}{ Upah tenaga kerja industri tekstil dan garmen naik 14.5 persen dan 15 persen. } \\
\hline \multicolumn{7}{|l|}{ Liberalisasi perdagangan. } \\
\hline \multicolumn{7}{|c|}{ Kombinasi 4, PDB Indonesia naik 8 persen, dan populasi Indonesia naik 1.1 persen. } \\
\hline \multicolumn{7}{|c|}{$\begin{array}{l}\text { Kombinasi 3, 5, PDB Indonesia naik } 8 \text { persen, populasi Indonesia naik } 1.1 \text { persen, PDB Amerika Serikat naik } 3.1 \\
\text { persen, dan PDB Cina naik } 8.5 \text { persen. }\end{array}$} \\
\hline
\end{tabular}




\section{a. Penurunan Tingkat Suku Bunga Bank}

Kebijakan menurunkan suku bunga bank sebesar 5 persen merupakan salah satu kebijakan moneter yang dapat meningkatkan produksi tekstil Indonesia. Industri tekstil adalah industri yang bersifat padat modal (capital intensive) dibandingkan dengan industri garmen. Namun demikian penurunan suku bunga bank hanya sebesar 5 persen tidak direspon oleh produsen tekstil di Indonesia dengan menaikan produksi tekstilnya. Produksi tekstil Indonesia yang tidak berubah juga menyebabkan ekspor tekstil Indonesia tidak berubah. Sedangkan impor tekstil Indonesia menurun sebesar 0,002 persen. Secara total penawaran tekstil Indonesia meningkat sebesar 0,057 persen. Sedangkan penurunan penawaran tekstil Indonesia tidak merubah volatilitas harga tekstil Indonesia sehingga permintaan tekstil Indonesia juga tidak berubah.

Harga garmen Indonesia yang tidak berubah, sebagai harga output bagi industri garmen, berkontribusi dalam menurunkan produksi garmen Indonesia sebesar 0,005 persen. Penurunan produksi garmen pada tahap selanjutnya akan mendorong penurunan ekspor garmen Indonesia sebesar 0,003 persen. Di sisi lain impor garmen meningkat sebesar 0,079 persen. Secara total, penawaran garmen Indonesia sedikit meningkat sebesar 0,0002 persen. Penurunan suku bunga bank sebesar 5 persen menyebabkan masyarakat cenderung tidak melakukan saving. Hal tersebut membuat permintaan garmen meningkat sebesar 0,0002 persen.

\section{b. Penyesuaian Nilai Tukar Rp. 9000 terhadap US\$}

Nilai tukar yang relatif tidak berfluktuasi akan membantu produsen dalam menghitung dan menentukan biaya produksi dan risiko usaha. Oleh sebab itu kebijakan moneter ini mampu meningkatkan ekspor tekstil dan garmen Indonesia, masing-masing sebesar 6.059 persen dan 21.676 persen. Secara bersama-sama pula juga meningkatkan impor tekstil sebesar 0,167 persen dan menurunkan impor garmen sebesar 5.175 persen. Total penawaran tekstil dan garmen Indonesia menurun, masing-masing sebesar 11.924 persen dan 63.908 persen.

Penawaran tekstil Indonesia yang menurun menyebabkan harga tekstil Indonesia meningkat sebesar 0,534 persen, sehingga permintaan tekstil Indonesia menurun sebesar 0,282 persen. Harga tekstil Indonesia yang meningkat pada gilirannya akan membuat produksi garmen Indonesia menurun sebesar 0,002 persen.

Kebijakan penyesuaian nilai tukar juga mendorong ekspor garmen Indonesia sebesar 21.676 persen. Penurunan harga garmen Indonesia sebesar 0,722 persen makin menstimulasi peningkatan eksportasi, menurunkan impor garmen Indonesia sebesar 5.175 persen, dan meningkatkan permintaan garmen Indonesia sebesar 0,129 persen. Selain itu dampak lainnya 
adalah penurunan produksi garmen Indonesia sebesar 0,002 persen. Secara total penawaran garmen Indonesia menurun sebesar 63.908 persen.

\section{c. Kenaikan Upah Tenaga Kerja Industri Tekstil dan Garmen}

Industri tekstil dan garmen banyak menyerap tenaga kerja, khususnya tenaga kerja wanita. Kebijakan peningkatan upah tenaga kerja di kedua sektor tersebut masing-masing sebesar 14.5 persen dan 15 persen akan mendorong penurunan produksi tekstil dan garmen. Produksi tekstil Indonesia menurun sebesar 25.411 persen. Ekspor tekstil Indonesia akan terdorong turun sebesar 8.965 persen dan impor tekstil Indonesia meningkat sebesar 0,552 persen. Secara total penawaran tekstil Indonesia menurun sebesar 34.307 persen.

Penurunan penawaran tekstil Indonesia akan menaikan harga tekstil Indonesia sebesar 1.804 persen. Dampak selanjutnya permintaan tekstil Indonesia menurun sebesar 73.455 persen. Bagi produksi garmen Indonesia, kenaikan harga tekstil Indonesia akan menurunkan produksi garmen Indonesia sebesar 12.630 persen. Ekspor garmen Indonesia pada tahap selanjutnya ikut mengalami penurunan, yaitu sebesar 4.798 persen. Impor garmen Indonesia akan meningkat sebesar 125.151 persen, sehingga secara total penawaran garmen Indonesia menurun, sebesar 18.735 persen.

Selain itu harga garmen Indonesia naik sebesar 1.283 persen, sebagai akibat tidak langsung dari kenaikan upah tenaga kerja. Pada akhirnya hal ini akan membuat permintaan garmen Indonesia menurun sebesar 0,237 persen.

\section{d. Liberalisasi Perdagangan Tekstil dan Produk Tekstil}

Liberalisasi perdagangan dengan penurunan tarif hingga nol persen sebagai salah satu bentuk kebijakan perdagangan, ternyata memberikan dampak pada peningkatan impor tekstil Indonesia sebesar 13.735 persen. Penurunan produksi tekstil dalam negeri sebesar 0,290 persen makin memperbesar peningkatan impor tersebut. Peningkatan impor tekstil Indonesia akan meningkatkan penawaran tekstil Indonesia sebesar 12.433 persen. Peningkatan penawaran tekstil ternyata menurunkan harga tekstil Indonesia sebesar 0,601 persen, sehingga permintaan tekstil Indonesia meningkat sebesar 0,376 persen. Harga tekstil Indonesia yang menurun juga direspon oleh ekspor tekstil Indonesia yang meningkat sebesar 0,148 persen.

Penurunan tarif impor garmen hingga nol persen akan meningkatkan impor garmen Indonesia sebesar 179.891 persen, sehingga secara total penawaran garmen Indonesia meningkat sebesar 21.950 persen. Di sisi lain, harga garmen Indonesia yang meningkat sebesar 
0,481 persen membuat permintaan garmen Indonesia menurun sebesar 0,092 persen. Peningkatan harga garmen Indonesia menjadi insentif bagi produsen garmen Indonesia untuk meningkat produksinya, yaitu sebesar 0,001 persen. Selain itu harga garmen Indonesia yang meningkat juga mendorong peningkatan ekspor sebesar 0,024 persen di masa mendatang

\section{e. Kenaikan Upah Tenaga Kerja di Sektor Tekstil dan Garmen, Kenaikan PDB Indonesia, dan Kenaikan Jumlah Penduduk Indonesia}

Kombinasi kebijakan kenaikan upah tenaga kerja di sektor tekstil dan garmen, kenaikan PDB Indonesia sebesar 8 persen, dan kebijakan demografi melalui peningkatan jumlah penduduk sebesar 1.1 persen menjadikan produksi tekstil Indonesia menurun sebesar 25.411 persen sehingga mendorong penurunan ekspor tekstil Indonesia sebesar 8.965 persen. Di samping itu impor tekstil Indonesia meningkat sebesar 0,763 persen. Secara total penawaran tekstil Indonesia menurun sebesar 34.115 persen. Penurunan penawaran tekstil ini akan meningkatkan harga tekstil Indonesia sebesar 1.737 persen. Pada gilirannya keadaan tersebut membuat permintaan tekstil Indonesia menurun sebesar 73.456 persen.

Peningkatan PDB dan pertumbuhan penduduk Indonesia secara alami mendorong peningkatan permintaan garmen Indonesia sebesar 3.268 persen. Keadaan ini membuat harga garmen Indonesia meningkat sebesar 1.443 persen. Selain itu juga diakibatkan upah tenaga kerja di sektor garmen cukup mendominasi dalam biaya produksi yang pada akhirnya meningkatkan harga output industri garmen.

Peningkatan harga tekstil Indonesia sebagai harga input industri garmen dapat menurunkan produksi garmen Indonesia sebesar 12.630 persen. Sedangkan ekspor garmen Indonesia menunjukkan penurunan sebesar 4.801 persen. Hal ini karena harga garmen di dalam negeri yang meningkat ternyata menarik bagi produsen garmen Indonesia untuk menggarap pasar Indonesia. Di samping itu impor garmen Indonesia meningkat sebesar 126.832 persen. Secara total penawaran garmen Indonesia menurun sebesar 18.522 persen

\section{f. Kenaikan Harga BBM, Liberalisasi Perdagangan Tekstil dan Produk Tekstil, Kenaikan PDB Indonesia, Amerika Serikat, dan Cina serta Kenaikan Jumlah Penduduk Indonesia}

Kebijakan kenaikan harga BBM sebesar 8.5 persen, liberalisasi perdagangan, kenaikan PDB Indonesia sebesar 8 Persen, peningkatan jumlah penduduk Indonesia sebesar 1.1 Persen, kenaikan PDB Amerika Serikat sebesar 3.1 Persen, dan PDB Cina sebesar 8.5 persen ternyata 
mampu menaikan produksi tekstil Indonesia, masing-masing sebesar 12.827 persen dan 1.585 persen. Oleh sebab itu ekspor tekstil Indonesia juga meningkat sebesar 4.926 persen dan sekaligus meningkatkan impor tekstil Indonesia sebesar 13.524 persen. Jadi secara total penawar tekstil Indonesia meningkat sebesar 29.746 persen. Keadaan ini membuat harga tekstil Indonesia menurun sebesar 1.536 persen, sehingga permintaan tekstil dalam negeri meningkat sebesar 0,847 persen.

Di sisi kenaikan PDB Indonesia dan jumlah penduduk Indonesia akan mendorong peningkatan permintaan garmen Indonesia sebesar 3.465 persen, sehinnga harga garmen Indonesia juga meningkat sebesar 0,321 persen. Eksportasi garmen Indonesia masih menunjukkan peningkatan sebesar 1.562 persen begitu pula dengan importasi garmen Indonesia yang meningkat sebesar 172.297 persen. Secara total penawaran garmen Indonesia meningkat sebesar 22.412 persen.

Peningkatan PDB Amerika Serikat dan Cina akan meningkatkan impor tekstil Amerika Serikat sebesar 1.341 persen dan impor tekstil Cina sebesar 5.746 persen. Oleh sebab itu total impor tekstil dunia akan meningkat sebesar 2.106 persen sehingga harga tekstil dunia meningkat sebesar 2.262 persen. Peningkatan harga ini akan berdampak pada peningkatan harga garmen Indonesia. Sedangkan di sisi garmen, peningkatan PDB Amerika Serikat akan mendorong peningkatan total impor garmen dunia sebesar 0,057 persen. Pada akhirnya peningkatan impor garmen dunia tersebut belum mampu meningkatkan harga garmen dunia. Hal ini terjadi karena total ekspor dunia meningkat lebih besar daripada impornya. Penurunan harga garmen dunia sebesar 18.690 persen akan berdampak pada penurunan harga tekstil Indonesia dan peningkatan harga garmen Indonesia.

\subsection{Diskusi}

Kenaikan produksi industri tekstil dan garmen pada umumnya terkait dengan peningkatan penyerapan tenaga kerja. Sedangkan ekspor industri tekstil dan garmen berhubungan dengan perolehan devisa yang diperlukan untuk menunjang pembangun ekonomi Indonesia. Kebijakankebijakan yang dapat menurunkan produksi dan sekaligus ekspor pada industri tekstil dan juga garmen adalah kebijakan menaikan upah tenaga kerja di sektor tekstil dan garmen masingmasing sebesar 14.5 persen dan 15 persen (simulasi 3) dan liberalisasi perdagangan, kenaikan PDB Indonesia dan jumlah penduduk (simulasi 5). Salah satu komponen biaya produksi yang berperan besar dalam keberlanjutan produksi tekstil dan garmen adalah upah tenaga kerja. Tenaga kerja yang dibutuhkan, khususnya pada industri garmen, adalah pekerja dengan keterampilan tertentu tanpa harus dengan tingkat pendidikan yang tinggi. Oleh sebab itu 
peningkatan penyerapan tenaga kerja industri TPT pada akhirnya dapat mengurangi jumlah pengangguran di masyarakat yang notabene muncul sebagai akibat keterbatasan mengenyam pendidikan tinggi. Kebijakan menaikkan upah tenaga kerja yang disebabkan oleh adanya kebijakan pemerintah, seperti kenaikan upah minimum regional, akan menstimulasi penurunan produksi dan ekspor, serta rasionalisasi tenaga kerja. Liberalisasi perdagangan TPT yang ditandai dengan penghapusan tarif hingga nol persen justru cenderung meningkatkan volume impor tekstil dan garmen Indonesia. Namun demikian di sisi lain ekspor tekstil Indonesia masih menunjukkan peningkatan, tapi tidak dengan ekspor garmen Indonesia. Hal ini terjadi terjadi persaingan yang semakin ketat antar negara produsen TPT di dunia, terutama Cina dan negaranegara di Asia Selatan.

Kebijakan yang hanya mampu meningkatkan produksi dan ekspor di salah satu sektor adalah kebijakan menaikkan tingkat suku bunga (simulasi 1). Kebijakan ini menurunkan produksi dan ekspor garmen Indonesia dan membuat produksi dan ekspor tekstil stagnan. Industri TPT merupakan salah satu dari industri yang berisiko tinggi, sehingga

bank kurang tertarik memberikan kredit investasi. Pada umumnya bank hanya memberikan pinjaman atau kredit jangka pendek (90 persen) dan jangka menengah (10 persen) kepada industri TPT. Sementara restrukturisasi permesinan industri TPT membutuhkan bentuk pinjaman dalam jangka panjang antara 10 sampai 15 tahun. Industri tekstil bersifat padat modal dibandingkan industri garmen, sehingga permasalahan restrukturisasi lebih banyak dirasakan oleh industri tekstil. Permesinan yang sudah usang dan teknologi yang tidak modern dapat mempengaruhi produktivitas industri TPT.

Kebijakan yang masih mampu meningkatkan produksi dan ekspor di kedua sektor adalah simulasi ke 2, yaitu kebijakan moneter melalui penyesuaian nilai tukar Rupiah terhadap US\$ dan simulasi ke 6, yaitu kombinasi kebijakan upah, liberalisasi, dan kenaikan PDB Indonesia serta beberapa negara maju. Semenjak Indonesia menganut floating exchange rate regime, nilai tukar Rupiah menjadi berfluktuasi sepanjang waktu. Meskipun demikian, bank Indonesia masih dapat melakukan intervensi untuk menstabilkannya melalui instrumen kebijakan moneter. Nilai tukar Rupiah yang stabil membantu eksportir dan importir dalam menghitung dan memprediksikan biaya dan sekaligus keuntungan di masa mendatang. 


\section{KESIMPULAN}

Faktor-faktor yang mempengaruhi perkembangan industri TPT Indonesia adalah sebagai berikut:

1. Produksi tekstil Indonesia dipengaruhi oleh lag harga kapas dunia dan perubahan lag upah tenaga kerja di sektor industri tekstil dengan hubungan yang negatif. Produksi garmen Indonesia dipengaruhi oleh lag upah tenaga kerja di sektor garmen.

2. Ekspor tekstil Indonesia ke pasar dunia bersifat elastis dalam jangka panjang terhadap perubahan harga tekstil Indonesia. Sedangkan ekspor garmen Indonesia di pasar dunia dipengaruhi oleh lag nilai tukar terhadap US\$ dengan hubungan yang positif.

3. Permintaan tekstil Indonesia mempunyai respon yang elastis terhadap lag upah tenaga kerja di sektor industri tekstil dan permintaan garmen Indonesia dipengaruhi oleh pendapatan per kapita penduduk Indonesia dengan hubungan yang positif.

Berdasarkan simulasi kebijakan yang dilakukan, dapat disimpulkan bahwa:

1. Kebijakan yang dapat meningkatkan produksi dan ekspor di industri tekstil dan garmen adalah (1) kebijakan tunggal melalui penyesuaian nilai tukar Rupiah terhadap US\$ dan (2) kombinasi kebijakan menaikkan upah, kebijakan liberalisasi perdagangan, dan kenaikan PDB Indonesia serta beberapa negara maju sebagai bentuk potensi pasar TPT dunia.

2. Kebijakan menurunkan produksi dan ekspor di industri tekstil dan garmen adalah (1) kebijakan tunggal melalui kenaikan upah tenaga kerja di industri tekstil dan garmen dan (2) kombinasi kebijakan menaikan upah tenaga kerja di industri tekstil dan garmen, kenaikan PDB Indonesia, dan kebijakan demografi melalui pertumbuhan penduduk Indonesia.

Secara keseluruhan dari hasil pendugaan koefisien parameter dan simulasi kebijakan menunjukkan bahwa menaikkan suku bunga bank untuk kegiatan investasi, BBM, dan juga upah tenaga kerja di sektor industri tekstil dan garmen, dapat menurunkan produksi tekstil dan garmen domestik di masa depan. Harga kapas dunia juga mempengaruhi penurunan ekspor tekstil dan garmen Indonesia. Sedangkan penyesuaian nilai tukar Rupiah akan mendorong peningkatan ekspor tekstil dan garmen Indonesia pada periode tahun 2007 sampai 2012.

Kesimpulan ini memberikan beberapa implikasi sebagai berikut:

1. Produksi industri TPT Indonesia yang meningkat dapat mendorong peningkatan penyerapan tenaga kerja. Oleh sebab itu diperlukan insentif ekonomi, antara lain melalui penurunan suku bunga bank untuk investasi.

2. Ekspor TPT Indonesia yang meningkat dapat meningkatkan penerimaan devisa negara. Peningkatan ekspor TPT dapat dipacu melalui penyesuaian nilai tukar Rupiah Rp 9 000/US\$. Nilai tukar Rp/US\$ yang relatif stabil akan membantu produsen TPT dalam menghitung biaya bahan baku dan keuntungan. 
3. Pengembangan tanaman kapas, sebagai salah satu bahan baku utama, perlu segera diwujudkan. Ketergantungan yang sangat tinggi terhadap kapas impor dapat menurunkan posisi daya saing TPT Indonesia di pasar dunia. 


\section{DAFTAR PUSTAKA}

Agustineu, S. D. 2004. Analisis Faktor-Faktor yang Mempengaruhi Output Industri Tekstil di Jawa Barat. Skripsi Sarjana. Fakultas Ekonomi dan Manajemen, Institut Pertanian Bogor, Bogor.

BPS. 2009. Statistik Indonesia 2008. Badan Pusat Statistik, Jakarta. 2010. Indikator Ekonomi, Buletin Statistik Bulanan. Badan Pusat Statistik, Jakarta.

CIC. 2004, Prospek Industri Garmen Indonesia. Indocommercial, No. 350. PT. Capicorn Indonesia Consultant, Inc, Jakarta.

Dunn, R. M. Jr. and J. H. Mutti. 2004. International Economics. Sixth Edition. Routledge Tailor and Francis Group, London.

Gonarsyah, I. 1987. Landasan Perdagangan Internasional. Departemen Ilmu-Ilmu Sosial dan Ekonomi Pertanian. Institut Pertanian Bogor, Bogor.

Henderson, J. M. and R. E. Quandt. 1980. Microeconomic Theory, A Mathematical Approach. McGraw Hill International Book Company, London.

Houck, J. P. 1986. Elements of Agricultural Trade Policies. MacMillan Publishing Company, New York.

Istojo, D. 2002. Analisis Struktur Industri Tekstil dan Produk Tekstil Indonesia terhadap WTO 2005. Tesis Magister Manajemen. Program Pascasarjana, Universitas Gadjah Mada, Yogyakarta.

Koutsoyiannis, A. 1978. Theory of Econometrics: An Introductory Exposition of Econometrics Methods. Second Edition. Harper \& Row Publishers, Inc., Barner \& Noble Import Division, New York.

Krantz, O., 2006, "Small European Countries in Economic Internationalisation: An Economic Historical Perspektive". Umea Universitet, Umea-Swedia. Umea Papers in Economic History. Mlachila, M. and Y. Yang, 2004, "The End of Textiles Quotas: A Case Study of the Impact of Bangladesh". International Monetary Fund, Washington DC. IMF Working Paper No. 04/ 108.

PRB. 2009. World Population Data Sheet 2009. Population Reference Bureau and USAID, Washington DC.

Pracoyo, A. 1995. Pengaruh GATT terhadap Perekonomian Indonesia, Studi Kasus Ekspor Industri Tekstil. Tesis Magister Manajemen. Program Pascasarjana, Universitas Gadjah Mada, Yogyakarta. 
Sinaga, B. M. 1989. Econometric Model of the Indonesian Hardwood Products Industry: A Policy Simulation Analysis. PhD, Dissertation. University of The Philippines, Los Banos.

Sunarno, S. 2008. ASEAN, Basis Produksi TPT Dunia. Indonesian Textile Serial Online. http:// indonesiatextile.com/index.php?option=com_content\& task=view\&id=73\&ltemid=50. Diakses tanggal 17 Maret 2010.

2008 Amankan Pasar Dalam Negeri. Indonesia Textile Serial Online. http:// indonesiatextile.com/index.php?option=com_content\&task =view\&id=76\&ltemid=50, Diakses Tanggal 17 Maret 2010.

Thoburn, J., 2010, "The Impact of World Recession on the Textile and Garment Industries of Asia". United Nations Industrial Development Organization, Vienna. Working Paper No. 17. UNCTAD. 2005. TNCs and the Removal of Textiles and Clothing Quotas. United Nations Conference on Trade and Development, Geneva.

VBN. 2011. Vietnam Textile and Garment Export Cross $\$ 11.2$ Biliion in 2010. Vitenam Business

News. Serial Online, http://vietnambusiness.asia/vietnam-textile-and-garment-exports-cross11-2b-in-2010/. Diakses tanggal 10 Januari 2011.

Wintala. 1999. Analisis Faktor-Faktor yang Mempengaruhi Ekspor Tekstil Indonesia: Ke Amerika Serikat, Inggris dan Jepang Tahun 1978-1997. Tesis Magister Manajemen. Program Pascasarjana, Universitas Gadjah Mada, Yogyakarta.

WTO. 2005. International Trade Statistics 2005. World Trade Organization, Geneva. 


\section{Lampiran}

Tabel 1.

Keterangan Peubah Endogen dan Eksogen yang Digunakan dalam Model

\begin{tabular}{|c|c|}
\hline $\mathrm{PTD}_{\mathrm{t}}$ & : Produksi tekstil domestik tahun t (1000 ton) \\
\hline PTD $_{t-1}$ & : Produksi tekstil domestik tahun $\mathrm{t}-1$ (1 000 ton) \\
\hline$P G D_{t}$ & : Produksi garmen domestik tahun t (1000 ton) \\
\hline$P G D_{t-1}$ & : Produksi garmen domestik tahun t-1 (1000 ton) \\
\hline$H T D R_{t}$ & : Harga riil tekstil domestik tahun t (USD/ton) \\
\hline$H T D R_{t-1}$ & : Harga riil tekstil domestik tahun t-1 (USD/ton) \\
\hline$H C W R_{t-1}$ & : Harga riil kapas dunia tahun t-1 (cent/pound) \\
\hline $\mathrm{HTWR}_{\mathrm{t}}$ & : Harga riil tekstil dunia tahun $\mathrm{t}$ (USD/ton) \\
\hline$H T W R_{t-1}$ & : Harga riil tekstil dunia tahun t-1 (USD/ton) \\
\hline$H M T I R_{t-1}$ & : Harga impor tekstil Indonesia tahun t-1 (USD/ton) \\
\hline $\mathrm{HGDR}_{\mathrm{t}}$ & : Harga riil garmen domestik tahun t (USD/ton) \\
\hline$H_{G D R}{ }_{t-1}$ & : Harga riil garmen domestik tahun t-1 (USD/ton) \\
\hline$H G W R_{t}$ & : Harga riil garmen dunia tahun $\mathrm{t}$ (USD/ton) \\
\hline $\mathrm{HGWR}_{\mathrm{t}-1}$ & : Harga riil garmen dunia tahun t-1 (USD/ton) \\
\hline$H M G I R_{t}$ & : Harga riil impor garmen Indonesia tahun t (USD/ton) \\
\hline $\mathrm{IRR}_{\mathrm{t}}$ & : Tingkat suku bunga riil bank tahun $\mathrm{t}$ (\%/tahun) \\
\hline $\mathrm{IRR}_{\mathrm{t}-1}$ & : Tingkat suku bunga riil bank tahun $\mathrm{t}-1$ (\%/tahun) \\
\hline UTKTR $_{\mathrm{t}-1}$ & : Upah riil tenaga kerja industri tekstil tahun t-1 (Rp juta) \\
\hline UTKGR $\mathrm{t}_{\mathrm{t}-1}$ & : Upah riil tenaga kerja industri tahun t-1 (1 $000 \mathrm{Rp})$ \\
\hline $\mathrm{BBMR}_{\mathrm{t}}$ & : Harga riil BBM tahun $\mathrm{t}(\mathrm{Rp} / \mathrm{liter})$ \\
\hline $\mathrm{BBMR}_{\mathrm{t}-1}$ & : Harga riil BBM tahun $\mathrm{t}-1$ (Rp/liter) \\
\hline $\mathrm{T}$ & : Tren waktu \\
\hline $\mathrm{XTI}_{\mathrm{t}}$ & : Ekspor tekstil Indonesia tahun t (1 000 ton) \\
\hline $\mathrm{XTI} \mathrm{t}-1_{1}$ & : Ekspor tekstil Indonesia tahun t-1 (1 000 ton) \\
\hline$X G l_{t}$ & : Ekspor garmen Indonesia tahun t (1000 ton) \\
\hline$\left.X G\right|_{t-1}$ & : Ekspor garmen Indonesia tahun t-1(1000 ton) \\
\hline $\mathrm{ERIR}_{\mathrm{t}}$ & : Nilai tukar riil Rupiah terhadap USA tahun t (Rp/USD) \\
\hline $\mathrm{ERIR}_{\mathrm{t}-1}$ & : Nilai tukar riil Rupiah terhadap USA tahun t-1 (Rp/USD) \\
\hline DKG & : Dummy integrasi perdagangan TPT dunia \\
\hline $\mathrm{STD}_{\mathrm{t}}$ & : Penawaran tekstil domestik tahun $\mathrm{t}$ (1 000 ton) \\
\hline$S G D_{t}$ & : Penawaran garmen domestik tahun t (1000 ton) \\
\hline
\end{tabular}




\section{Tabel 1.}

Keterangan Peubah Endogen dan Eksogen yang Digunakan dalam Model (lanjutan)

\begin{tabular}{|c|c|}
\hline $\mathrm{MTI}_{\mathrm{t}}$ & Impor tekstil Indonesia tahun t (1 000 ton) \\
\hline $\mathrm{MTI}_{\mathrm{t}-1}$ & Impor tekstil Indonesia tahun t-1 (1000 ton) \\
\hline$M G I_{t}$ & Impor garmen Indonesia tahun t (1 000 ton) \\
\hline$M G I_{t-1}$ & Impor garmen Indonesia tahun t-1 (1 000 ton) \\
\hline $\mathrm{DTD}_{\mathrm{t}}$ & Permintaan tekstil domestik tahun t (1 000 ton) \\
\hline DTD $_{t-1}$ & Permintaan tekstil domestik tahun t-1 (1000 ton) \\
\hline$D_{G} D_{t}$ & Permintaan garmen domestik tahun t (1000 ton) \\
\hline$D G D_{t-1}$ & Permintaan garmen domestik tahun t-1 ( 1000 ton) \\
\hline $\mathrm{TFT}_{\mathrm{t}-1}$ & Tarif impor tekstil tahun t-1 (\%/tahun) \\
\hline $\mathrm{TFG}_{\mathrm{t}}$ & Tarif impor garmen tahun $\mathrm{t}$ (\%/tahun) \\
\hline $\mathrm{GDPIR}_{\mathrm{t}}$ & PDB riil Indonesia (Rp 1000) \\
\hline GDPIR $_{\mathrm{t}-1}$ & PDB riil Indonesia t-1 (Rp 1000) \\
\hline $\mathrm{POPI}_{\mathrm{t}}$ & Jumlah penduduk indonesia tahun t (juta jiwa) \\
\hline $\mathrm{POP}_{\mathrm{t}-1}$ & Jumlah penduduk Indonesia tahun t-1 (juta jiwa) \\
\hline $\mathrm{MGB}_{\mathrm{t}}$ & Impor garmen bekas tahun t (1 000 ton) \\
\hline$M G B_{t-1}$ & Impor garmen bekas tahun t-1 (1 000 ton) \\
\hline $\mathrm{XTW}_{\mathrm{t}}$ & Ekspor tekstil dunia tahun t (USD/ton) \\
\hline MTW $_{t}$ & Impor tekstil dunia tahun t (1 000 ton) \\
\hline MTW $_{\mathrm{t}-1}$ & Impor tekstil dunia tahun t-1 (USD/ton) \\
\hline $\mathrm{XTG}_{\mathrm{t}}$ & Ekspor tekstil Jerman tahun t (1 000 ton) \\
\hline $\mathrm{XTA}_{\mathrm{t}}$ & Ekspor tekstil USA tahun t (1000 ton) \\
\hline $\mathrm{XTC}_{\mathrm{t}}$ & Ekspor tekstil China tahun t (1 000 ton) \\
\hline $\mathrm{XTR}_{\mathrm{t}}$ & Sisa ekspor tekstil dunia tahun t (1 000 ton) \\
\hline $\mathrm{MTL}_{\mathrm{t}}$ & Impor tekstil Italia tahun t (1 000 ton) \\
\hline $\mathrm{MTA}_{t}$ & Impor tekstil USA tahun t (1 000 ton) \\
\hline $\mathrm{MTC}_{\mathrm{t}}$ & Impor tekstil China tahun t (1000 ton) \\
\hline$X G W_{t}$ & Ekspor garmen dunia tahun t (1 000 ton) \\
\hline $\mathrm{MGW}_{\mathrm{t}-1}$ & Impor garmen dunia tahun t-1 (1 000 ton) \\
\hline & Ekspor garmen dunia tahun t (1 000 ton) \\
\hline $\mathrm{MGW}_{\mathrm{t}}$ & Impor garmen dunia tahun t (1 000 ton) \\
\hline $\mathrm{MGW}_{\mathrm{t}-1}$ & Impor garmen dunia tahun t-1 (1 000 ton) \\
\hline & Ekspor garmen China tahun t (1 000 ton) \\
\hline
\end{tabular}




\section{Tabel 1.}

Keterangan Peubah Endogen dan Eksogen yang Digunakan dalam Model (lanjutan)

$\mathrm{XGT}_{\mathrm{t}} \quad:$ Ekspor garmen Turki tahun $\mathrm{t}$ (1 000 ton)

$X_{\mathrm{XGR}} \quad$ : Sisa ekspor garmen dunia tahun $\mathrm{t}$ (1 000 ton)

$\mathrm{MGG}_{\mathrm{t}} \quad$ : Impor garmen Jerman tahun $\mathrm{t}$ (1 000 ton)

MGA $_{t} \quad:$ Impor garmen USA tahun $\mathrm{t}$ (1 000 ton)

MGJ $_{\mathrm{t}} \quad$ : Impor garmen Jepang tahun $\mathrm{t}$ (1 000 ton)

$\mathrm{MGR}_{\mathrm{t}} \quad$ : Sisa impor garmen dunia tahun $\mathrm{t}$ (1 000 ton) 